\title{
ACCOUNTING FOR RACIAL DIFFERENCES IN HOUSING CREDIT MARKETS
}

by Robert B. Avery, Patricia E. Beeson, and Mark S. Sniderman

Robert B. Avery is an associate professor in the Department of Consumer Economics and Housing at Cornell University, Ithaca, New York, and Patricia E. Beeson is an associate professor of economics at the University of Pittsburgh; both are research associates at the Federal Reserve Bank of Cleveland. Mark S. Sniderman is vice president and associate director of research at the Federal Reserve Bank of Cleveland. This paper was presented at the Conference on Discrimination and Mortgage Lending: Research and Enforcement, sponsored by the Department of Housing and Urban Development, Washington, D.C., May 18-19, 1993. The authors would like to thank Glenn Canner, Stuart Gabriel, Stuart Rosenthal, John Yinger, and Peter Zorn for helpful comments.

Working papers of the Federal Reserve Bank of Cleveland are preliminary materials circulated to stimulate discussion and critical comment. The views stated herein are those of the authors and not necessarily those of the Federal Reserve Bank of Cleveland or of the Board of Governors of the Federal Reserve System. 


\begin{abstract}
The release of individual housing credit application data, combined with lender and neighborhood information required by amendments to the Home Mortgage Disclosure Act (HMDA) in 1989, has offered new opportunities to examine the roles of both neighborhood and individual race in credit availability. The extent to which objective lending criteria are responsible for observed differences in home mortgage credit denial rates, versus discrimination based on income, race, or neighborhood (redlining), has been the subject of considerable debate.

This paper provides a more detailed documentation of racial and neighborhood differences in denial rates than has previously been available. Using estimates from a fixed-effects linear probability model to decompose racial differences in application denial rates, the authors find persistent variations between white and minority applicants, particularly blacks. The variance is widespread and remains even after lender, neighborhood, and applicant economic characteristics are accounted for. While the HMDA data do not contain enough relevant information about the loan applications to draw any firm conclusions about the reasons for these differences, some possibilities include property location, credit or employment histories, loan-to-value ratios, or other factors considered in the loan evaluation process that are not included in the HMDA file.
\end{abstract}




\section{Introduction}

Despite the passage of several laws related specifically to racial differences in housing credit availability, data constraints have limited the number of studies of this issue. ${ }^{1}$ Most existing studies use census-tract-level or lender-level data collected under the Home Mortgage Disclosure Act (HMDA) to infer racial differences. Although findings from such work are by necessity indirect, there is a persistent inference of substantial differences in the availability of mortgage and other credit across racial groups. Unfortunately, most of this work has been hampered by the inability to separate the effects of the race of the applicant from the racial composition of the applicant's neighborhood. ${ }^{2}$ Studies that use detailed applicant-level information to examine the direct effects on mortgage denial rates of both property location and the race of the applicant are rare. ${ }^{3}$

The release of individual application data, combined with lender and neighborhood data as required by amendments to the HMDA in 1989, offers unprecedented new opportunities to examine the issue of the role of both neighborhood and individual race in credit availability. Early reports based on the 1990 HMDA data document differences in denial rates on home mortgage credit applications by race and income of applicants and by the average income and racial composition of neighborhoods (see Avery, Beeson, and Sniderman [1993a] and Canner and Smith [1991, 1992]). The extent to which objective lending criteria are responsible for these differences, versus discrimination based on income, race, or neighborhood (redlining), has been the subject of much analysis and debate.

In this paper, we provide a more detailed documentation of racial and 
neighborhood differences in denial rates than has henceforth been available. For each of three loan products (home purchase, refinance, and home improvement), we use estimates from a fixed-effects linear probability model to decompose racial differences in application denial rates into five components reflecting the portion attributable to 1) economic characteristics of the applications reported in HMDA (income, loan amount, loan type, etc.), 2) overall denial rates of the lenders receiving the application, 3) the metropolitan statistical areas (MSAs), 4) census tract locations of the property, and 5) an unexplained residual. We then compare these components across MSAs, across neighborhood types grouped by income and racial composition, across types of lenders, and for central city and suburban areas. We also compare racial differences in denial rates across applications grouped by predicted denial rates based on all factors except race.

Our objective in conducting this analysis is twofold. First, we are interested in determining whether racial differences in credit approvals reflect activity in a small subset of markets or whether they are endemic to most markets. Although significant media attention has been paid to the issue of race and mortgage lending, preliminary studies using the HMDA data have been limited in scope and restricted to either individual cities or specific loan products. For example, in a study that has received wide media publicity (Munnell et al. [1992]), the Boston Federal Reserve Bank conducted an expanded survey of loan applications in the Boston area and concluded that even when an extensive list of individual applicant characteristics was controlled for, black and Hispanic applicants were significantly more likely to be denied than white applicants. This study, however, was limited to one loan product (home purchase loans) and one 
city. Thus, it is not clear whether the authors' conclusions can be generalized or are specific to certain areas. Second, as stated above, we are interested in determining whether racial differences in lending stem from variations in applicant characteristics (other than race), differences in the neighborhoods in which properties are located, or racial differences that cannot be explained by these factors.

By way of preview, we find that denial rates for minority applicants are consistently higher than those for white applicants with otherwise identical attributes (as reported in the HMDA data) who are applying for loans with the same lenders, and for properties located in the same neighborhoods. We also find significant neighborhood effects that differ across racial groups: Blacks, in particular, are more likely to apply for loans for properties in neighborhoods with higher denial rates, ceteris paribus, than are white applicants. On average, these neighborhood effects are less pronounced than individual effects, although they are almost equal for home improvement loans. We find a remarkable degree of consistency in these conclusions across geographic markets and loan products, indicating that the observed racial differences in denial rates are widespread and cannot be attributed to a small subset of markets. Although our analysis reveals substantial and consistent differences in denial rates related to the race of the applicant, even after controlling for a number of applicant characteristics, we emphasize that the HMDA data do not contain enough relevant information about the loan applications to draw any firm conclusions about the reasons behind these phenomena. These residual differences may be due to credit histories, employment histories, loan-tovalue ratios, or other factors considered in the loan evaluation process that are not 
included in the HMDA file, or may be the result of differential treatment based solely on the race of the applicant.

The remainder of this paper is organized as follows. In the next section we present a simple framework for analysis. In section II we provide a brief description of the HMDA data and summary sample statistics. Section III summarizes our results, and concluding remarks are given in section IV.

\section{Framework and Empirical Model}

Consider the following simple, yet fairly general, framework in which to evaluate the empirical findings of this study. Assume that the risk of each loan application given all available ex ante information can be expressed as a risk score, RS. Further assume that each lender decides to approve or deny an application based on a comparison of its risk score and the lender's maximum acceptable risk. If the risk score is above a cutoff, c, the loan is denied; otherwise the loan is accepted. Note that this abstracts from the issue of price by assuming either that lenders price all loans equally or, because of problems of moral hazard and adverse selection, that lenders have a maximum risk acceptable at any price.

This model of lender behavior is deterministic, but in reality error is likely to enter the process. First, lenders may not know, or use, all available information in computing risk scores. In this case, RS would be their estimate of the applicant's risk given the information they use, and the loan-granting decision would still be made deterministically, but based on a different set of information. To a researcher attempting 
to quantify lender behavior, this case seems identical to the full information case (assuming the researcher has access to all information used by the lender). A second potential source of error is more relevant for this paper. Lenders may use risk score (or their own estimate) and behave deterministically, but an external researcher may only observe the lender's assessment of risk with error. That is, researchers may observe a set of instruments for risk score for which they believe

(1) $\mathrm{RS}=\mathrm{X} \beta+\mathrm{e}$,

where $\mathrm{e}$ is a stochastic error term. This implies that

(2) Denial $=1$ if $X^{\prime} \beta+e>c$, and

Denial $=0$ otherwise

To an external researcher, who does not observe e, the evaluation process appears to be probabilistic.

If only the lender action (accept/deny), and not the risk score, is observed, estimation of the parameters in equation (1) requires assumptions about the error term, e. If the error in (1) is assumed to be uniform, then the probability that a loan application will be denied, given $\mathrm{X}$, is proportional to $\mathrm{X}^{\prime} \beta$ plus a constant, and the parameters in (1) will be estimable from a linear probability model. If e is normal, then equation (2) gives rise to a probit probability model; and if $\mathrm{e}$ is double exponential, then (2) gives rise to a logistic probability model. Although the scaling of parameters depends critically on the model form, the relative magnitude and signs of the parameters are likely to be robust with respect to the model form chosen.

Of particular interest for this paper is the robustness (and interpretation) of racial 
shift factors that may appear in $\mathbf{X} \boldsymbol{\beta}$. Racial shifts may appear for several reasons. First, race itself may be a predictor of future behavior and thus enter the risk score directly. This might occur, for example, because minorities face discrimination in labor markets and thus have more variable income. This would appear as different risk scores for otherwise equal applications of different racial groups, or as racial shifts in estimated $\beta$ s. Note that for reasons of cost, lenders may choose to use estimates of RS rather than fully computing it. In this case, race might be an instrument for the variables they do not use.

Second, lenders may practice overt discrimination, and set a lower cutoff, c, for minorities. To an observer who looks only at the accept/deny process, this case would be observationally equivalent to the first case. Overt discrimination may also take the form of lenders (or a subset of lenders) randomly denying a fixed percentage of minorities. This will also produce a racial shift.

Third, lenders may in fact not use race, and there may not be any racial shifts in the true risk scores. However, race may be correlated with the omitted variables in the error term, $e$, in equation (1). Minority applications could differ from others in the expectation of e given $\mathrm{X}$. To the external researcher measuring $\mathrm{RS}$ with error, racial shifts would show up in estimated $\beta$ s, making this observationally equivalent to the first two cases, even though race is not used by lenders and does not enter RS. Note that the better that $\mathrm{X}$ is specified, the less this effect should matter.

We might also observe a combination of these effects. For example, only a subset of lenders might have lower risk thresholds for minority applications. In this instance, 
racial shifts would represent the average lender effect. Moreover, they would also imply consistent residual differences across lenders in overall denial rates (we would expect differences across lenders for other reasons, such as price or preferences for risk). We might also observe combinations of different racial cutoffs and variations in the expected values of the omitted variables, e. Again, the measured residual differences correlated with race would represent a combination of effects.

The important point to emphasize here is that each of these sources of racial shifts, with very different policy implications, is likely to produce observationally equivalent results. Moreover, the estimated shifts will be sensitive to the econometric model form chosen. Unfortunately, there is little other than computational convenience to argue for a particular form (we actually employ a linear probability model for this reason). Thus, despite the obvious value in quantifying racial shifts in denial functions, these estimates, regardless of what they are, will be incapable of distinguishing among competing causal models.

\section{Empirical Model}

Our empirical specification follows the framework set out above. We assume that each mortgage application's risk can be represented as a function of the economic characteristics (such as income), neighborhood, market, lender, and race of the applicant. As noted above, we have no basis with which to select a particular econometric model specification. However, the size of the data set dictates that in practice we assume a linear probability model specification. We thus estimate a model where the probability that a random loan application would be denied is linear in the following terms: 
(3) DENIAL $_{\mathrm{MMTL}}=\beta_{\mathrm{A}} \mathrm{AC}_{\mathrm{i}}+\beta_{\mathrm{R}} \mathrm{RACE}+\beta_{\mathrm{M}} \mathrm{MSA}_{\mathrm{M}}+\beta_{\mathrm{T}} \mathrm{TRACT}_{\mathrm{T}}+\beta_{\mathrm{L}} \mathrm{LENDER}_{\mathrm{L}}$ $+\mathrm{e}_{\mathrm{iMTL}}$,

where DENIAL is one if the $i^{\text {th }}$ application using the $L^{\text {th }}$ lender in the $M^{\text {th }}$ MSA and $T^{\text {th }}$ census tract is denied, and zero otherwise. MSA, TRACT and LENDER are dummy variables indicating which MSA, census tract, and lender the application relates to, and e is a residual. $\mathrm{AC}$ is a vector of application characteristics, other than race, reported in the HMDA data. AC includes gender, marital status, occupancy, income, loan amount, income-to-loan ratio, federal loan guarantee (Federal Housing Administration [FHA] or Department of Veterans Affairs [VA]). RACE is a dummy variable indicating the race of the applicant and co-applicant. The model is specified and estimated separately for each of three types of loan applications: home purchase, refinance, and home improvement.

To help minimize the possibility that the differences within and across neighborhoods we identify do not reflect nonlinearities in other effects that are correlated with location, we allow for a considerable degree of nonlinearity in the effects of individual characteristics in estimating equation (3). Income and loan amount are entered as linear spline functions with seven knots each, and the ratio of income to loan amount is entered as a series of six dummy variables. Moreover, a five-knot linear spline for income is interacted with a dummy variable indicating the presence of a co-applicant, and with dummy variables indicating that the application is for an FHA or VA loan. Similarly, a five-knot linear spline of loan amount, and the six dummy variables indicating ranges of values for the ratio of income to loan amount, are also interacted 
with a dummy variable indicating applications for FHA or VA loans. We also include dummy variables for six applicant and two co-applicant racial categories, and the racial dummies interacted with FHA and VA loan dummies.

To reduce the computing requirements, the actual estimation was done in two stages. In the first stage, equation (3) was estimated with the individual application characteristics (AC) and separate intercepts for each lender-census tract combination included as single-component fixed effects. ${ }^{4}$ The MSA, lender, and tract effects are thus intertwined in these effects. In the second stage, an iterative procedure (equivalent to regressing the fixed-effects intercepts against MSA, census tract, and lender dummies) was used to identify the MSA, tract, and lender effects. By construction, the MSA effects were normalized to have overall sample means of zero, and within each MSA, lender and tract means were normalized to zero. In cases where lender and tract effects were not identified (a lender was the only lender in a tract and did all of its business there), the effect was assigned to the tract.

\section{Data}

All commercial banks, savings and loan associations, credit unions, and other mortgage lending institutions (primarily mortgage bankers) that have assets of more than $\$ 10$ million, make at least one mortgage loan, and have an office in an MSA are required to report on each mortgage loan application acted upon by the institution during the calendar year. 5 They must report the loan amount, the census tract of the property (if in an MSA), whether the property is owner-occupied, the purpose of the 
loan (home purchase, home improvement, or refinancing), loan guarantee (conventional, FHA, VA), action taken by the lender (loan approved and originated, application approved but withdrawn, application denied), the race and gender of the loan applicant (and co-applicant, if any), and the income relied upon by the lending institution in making the loan decision. ${ }^{6}$

In total, 9,333 financial institutions made HMDA filings for 1990 on $6,595,089$ loan applications. Our analysis focuses on the $3,489,235$ loan applications for $1-4$ family properties in MSAs that were acted upon by the lenders. ${ }^{7}$ Of these loans, $1,984,688$ were home purchase loans, 716,595 were applications to refinance existing mortgage loans, and 787,952 were applications for home improvement loans (generally second or third mortgages). These applications were received by 8,745 separate institutions operating in 40,008 census tracts in all 340 of the MSAs in the United States defined as of 1990. We define lenders at the MSA level: Thus, an institution reporting applications for two different MSAs is treated as two different lenders. There are 23,248 such lenders in our sample. ${ }^{8}$

Descriptive statistics for the applications reported in the 1990 HMDA are found in table 1. Statistics are given separately for home purchase, refinancing, and home improvement loan applications. Clearly, housing credit applicants are a select sample of American households. Household mean income $(\$ 63,071)$ is substantially higher than that reported for all households in the 1989 Survey of Consumer Finances $(\$ 35,700) .^{9}$ The racial composition of the study sample also appears to differ from that of all U.S. households. Blacks constituted 6.9 percent of the housing loan applicants, yet were 7.4 
percent of the homeowners and headed 11.2 percent of the households in 1990. Similarly, Asians, native Americans, and others accounted for 5.6 percent of the housing loan applicants but only 2.1 percent of the homeowners and 3.0 of the households. Hispanics were more evenly represented: 6.6 percent of the applicants, 4.1 percent of the homeowners, and 6.4 percent of the households. ${ }^{10}$

It is also apparent that denial rates differ substantially by race for all three types of loans (see table 2). Denial rates for black applicants are about twice as high as those for white applicants, and for Hispanic applicants the rate is about 50 percent higher than for whites. Other racial differences are also apparent, particularly with respect to black applicants. Black applicants are more likely to be single and are more likely to apply for federally guaranteed loans. In addition, a larger portion of loans originated to black applicants are subsequently sold, and credit history is given as a reason for denial more often. Furthermore, while the median income and loan amounts for black applicants are considerably lower than those for white applicants, the ratio of the two is fairly similar. In contrast, the ratio of median loan amount to median income is consistently higher for Hispanic applicants than for the other two racial groups.

\section{Results}

The parameter estimates for the denial rate regressions (equation [3]) are reported in tables 3, 4, and 5. ${ }^{11}$ A positive coefficient can be interpreted as the expected increase in the probability that an applicant's loan would be denied resulting from a one-unit increase in the independent variable holding all other variables constant 
- specifically, the applicant's MSA, census tract, and lender. Thus, the coefficients on race, for example, represent the expected difference in the probability that a white and black applicant with the same income, gender, FHA/VA status, loan amount, MSA, census tract, and lender will have their loan application denied. Thus interpreted, the estimated black/white (.103), Hispanic/white (.040) and, to a lesser extent, the native American/white (.028) and other race/white (.030) differences for conventional home purchase loans are quite significant. Differences are similar for FHA loans $(.116, .030$, .028 , and .040 , respectively). There is little residual difference between Asian and white denial rates on home purchase loans (.008).

Significant racial differences also exist for denial rates on refinance and home improvement loan applications. Compared with home purchase applications, the black/white difference is somewhat smaller for conventional refinance (.070) and home improvement (.080) loan applications. The same is true of the native American/white differences. However, for Hispanic, Asian, and other race applicants, differences from white denial rates for refinance and home improvement applications are larger than for home purchase applications. Interestingly, while there is little residual difference between Asian and white denial rates on home purchase loan applications, the disparity is sizable for refinance (.039) and home improvement (.054) applications --- comparable to the Hispanic/white differences.

In the remainder of this section, we focus on aggregate racial differences in denial rates. Gross denial rate differences are expressed as the sum of components representing differences in applicant characteristics (AC), neighborhood (TRACT), 
market (MSA), lender (LENDER), and an unexplained residual. In presenting figures for various applicant groups, components are averaged over all group members and expressed as percentages (by multiplying by 100 ) instead of fractions. By construction, these components must add up. Thus, for example, if 30 percent of an applicant group were denied, then the sum of the average AC, MSA, TRACT, and LENDER components and the average unexplained residual must equal 30 percent. Similarly, the difference in the percentage denial rates for two groups must equal the sum of the differences in their components.

Neighborhood, MSA, and lender effects are taken directly from the estimated components, TRACT, MSA, and LENDER. The component reflecting each applicant's economic characteristics, $\mathrm{AC}$, is computed using the coefficients from equation (3), assuming his or her race is white. The unexplained residual is then computed for each applicant as the difference between the lender's action (DENIAL [1] or ACCEPT [0]) and the predicted lender action based on the sum of AC, MSA, TRACT, and LENDER. It should be remembered that MSA, TRACT, and LENDER are normalized to have mean zero. Since the applicant characteristics, AC, are formed assuming the applicant is white, these normalizations imply that the unexplained residual for white applicants will be approximately, but not exactly, zero due to nonrandom distributions of white applicants across tracts, lenders, and MSAs.

\section{Racial Differences in Denial Rates - All Neighborhoods}

The average applicant, lender, MSA, neighborhood, and residual effects for black, Hispanic, Asian, native American, "other" race, white, and total applicants are 
reported in column 1 of tables 6,7 , and 8 . Because of the normalizations, these numbers by themselves are not particularly meaningful; it is the differences between the racial groups that are of interest. As summarized in table 1, for home purchase and refinance loan applications, the unexplained residual makes up most of the racial differences in percentage denial rates. The residual accounts for two-thirds of the 16.3 percentagepoint difference between black and white percentage denial rates on home purchase loan applications, and six-tenths of the 12.4 percent difference for refinance applications. While the Hispanic/white percentage denial rate differential is smaller (9.0 and 9.2 percentage points on home purchase and refinances, respectively), the residual still accounts for a significant portion of the difference (four-tenths for home purchases and slightly over half for refinances). The same is true for the other racial groups. Census tract locations also contribute to the racial differences in percentage denial rates on home purchase and refinance applications, but the contribution is much less than the residual associated with the race of the applicant.

For home improvement loan applications, the picture is somewhat different. While the residual still accounts for over a third of the difference, disparities in applicant characteristics (including lender and MSA) account for a sizable portion of the difference between white percentage denial rates and those for blacks and Hispanics. Moreover, census tract location accounts for a large share of the black/white differential.

There are some other notable differences across the three types of loans. First, racial differences in percentage denial rates are least pronounced for refinance loan applications. Second, for black applicants, the home purchase residual is larger than the 
refinance and home improvement residuals, while the opposite is true for Hispanic and Asian applicants. Finally, while the Asian percentage denial rate is virtually indistinguishable from the white percentage denial rate on home purchase applications, there are significant and largely unexplained differences between Asian and white percentage denial rates for the other loan products.

\section{Racial Differences in Denial Rates by Neighborhood Income and Racial Composition}

We now examine racial differences in percentage denial rates within and across census tracts, grouped on the basis of average applicant income: high income (mean income of all applications for loans in the tract of more than $\$ 60,000)$, middle income (mean income between $\$ 40,000$ and $\$ 60,000$ ) and low income (mean income of less than $\$ 40,000$ ); and racial composition: primarily white (tracts with less than 10 percent nonwhite applicants), mixed (10 to 30 percent nonwhite applicants), and primarily minority (more than 30 percent nonwhite). Percentage denial rates by neighborhood income and by neighborhood racial composition for black, Hispanic, Asian, and white applicants are given in columns $2-10$ of tables 6,7 , and 8 . We report the percent of the applications, the actual percentage denial rate, the portion attributable to applicant characteristics, MSA, lender, census tract, and the unexplained residual, for each for black, Hispanic, Asian, native American, white, and other race applicants, in each of the nine types of neighborhoods.

These tables reveal a remarkable persistence in the unexplained residual. While the size of the residual varies somewhat across loan type and across tracts that differ in mean income and racial composition, it is always relatively large. For black applicants, 
the unexplained residual for home purchase loans ranges from 9 to 14 percentage points across the nine types of neighborhoods; for refinance and home improvement, the range is only slightly lower -6 to 12 percentage points. For other minority groups, there is a comparable persistence across neighborhoods in the unexplained residual.

The tables also reveal a remarkable persistence in the census tract effects across racial groups. For all racial groups, applications for properties in predominantly minority and low-income neighborhoods have higher percentage denial rates than for those in predominantly white and high-income neighborhoods.

While the overall impression is one of consistency, a few systematic differences are evident. The difference between black and white percentage denial rates is lowest in primarily minority tracts, and in all neighborhoods the unexplained residual accounts for almost all of the difference, though there is a tendency for it to decline with neighborhood income. For Hispanics, on the other hand, the residual difference is slightly higher in the minority tracts and tends to increase with neighborhood income, though these patterns are weak. We tend to focus on minority-white comparisons, but there are also interesting differences across the minority groups. For example, in all but one type of neighborhood (low-income-mixed tracts), our model predicts a lower percentage denial rate for blacks than Hispanics. This lower predicted percentage denial rate, however, is swamped by the higher residuals for blacks, and as a result the overall percentage denial rates within each type of neighborhood are 5 to 10 percentage points higher for black applicants.

To examine the robustness of these results, a number of other comparisons were 
made. The sample was restricted to center city areas (table 9) and non-center-city areas (table 10). The sample was restricted by lender type (tables 11,12 , and 13). Neighborhoods were defined by the percentage of applicants that were black (table 14) and Hispanic (table 15). Data were also disaggregated by MSA, with results presented for the top 25 MSAs and grouped for smaller ones (tables 16, 17, and 18). In all cases, the results support the basic findings of tables 6,7 , and 8 .

Despite the apparent thoroughness of these robustness tests, there remains a concern that the validity of each of these findings rests upon the appropriateness of the same basic denial model, and our assumption that the form of this model is linear. To examine this assumption, one final robustness test was employed. Observations were grouped according to their predicted probability of denial based on AC, MSA, and LENDER. This could be considered a nonparametric rank-ordering of observations by risk (except for race and neighborhood). Average differences in the black/white and Hispanic/white unexplained residual and tract effects were then computed for each predicted denial probability group and are presented in tables 19 and 20. By construction, within each group the sum of the other predicted characteristics is the same for blacks and whites (or Hispanics and whites), so the sum of the residual and tract racial differences must equal the differences in racial percentage denial rates.

The linear probability model assumption implies that the differences in racial denial rates (and the residual and neighborhood subcomponents) should be constant across risk groups. If the underlying model form were logistic or probit, then the differences would be increasing as the denial probability rose from zero to 50 percent. 
The results presented in tables 19 and 20 suggest that whereas the residual and neighborhood group differences do rise when the denial probability increases from zero to 10 percent, they are fairly constant above that level. This suggests that the linear probability model specification is no less appropriate than the logistic or probit model form.

\section{Conclusions}

We find a persistent difference in the denial rates of white and minority applicants, particularly blacks. These differences remain even after lender, neighborhood, and applicant economic characteristics (as best we can measure them with the HMDA data) are accounted for. Moreover, we find a remarkable degree of consistency in these conclusions across geographic markets and loan products, indicating that the observed racial differences in denial rates are widespread and cannot be attributed to a subset of markets or type of lender.

It is by now well known that the HMDA data do not contain enough relevant information about the loan applications to draw any firm conclusions regarding the reasons for these differences. We cannot determine whether these findings are generated by a process of lender discrimination against minorities, because our residual differences may be due to credit histories, employment histories, loan-to-value ratios, wealth, or other factors that lenders consider in the loan evaluation process but that are not included in the HMDA file. Because our analysis excludes these variables, we cannot conclude that the unexplained residual unambiguously stems from differential 
treatment based solely on the race of the applicant. There is some evidence in the HMDA data that these variables may be correlated with race, as witnessed by the more prevalent citation of credit history as a reason for denial for minorities (table 2). Such a correlation could confound the estimation of the pure racial effect.

Despite this weakness of the HMDA data, our analysis does shed some light on the reasons for observed differences in denial rates across racial groups and neighborhoods. It has been argued that property location is an important source of racial differences in denial rates. Because house value appreciation tends to be lower in low-income and minority neighborhoods, these areas are considered to be more risky from the lenders' point of view. Moreover, some lenders argue that appraisals are harder to conduct and interpret in low-income and minority neighborhoods, because the housing stock is generally older and more heterogeneous, and because appraisers are less familiar with these neighborhoods. ${ }^{12}$ Our analysis indicates that property location does contribute to racial differences in denial rates, but on average neighborhood effects are smaller than those stemming from applicant characteristics. Moreover, when comparing similar applicants, racial differences in denial rates still exist and are roughly the same size within neighborhoods, regardless of the type of neighborhood.

Since there are a number of potential explanations for the racial differences we find in our residual denial rates, further study will be necessary to pinpoint the causes. For example, one explanation could be that factors observed by the lenders but not contained in our data are driving the results. If so, one would expect larger residual differences for home purchase loan denials than for refinance and home improvement 
loans, because the latter applicants are a select group that has already received at least one loan - the original home purchase loan. We find some evidence that this is the case: for black applicants, the residual denial rate is higher for home purchase loans than for refinances. Interestingly, this pattern does not hold for Asian and Hispanic applicants; their residual denial rates are greater for refinances than for home purchase loans. Moreover, for all minority groups there are sizable unexplained residuals for refinance and home improvement loan applications as well as for home purchase applications, suggesting that having once qualified for a new home loan brings little useful information to the regressions. Exactly what kind of process could generate these outcomes for different credit products requires more thought.

One possibly fruitful approach would be to pay more attention to the individual lenders and their characteristics. In several previous studies (Avery, Beeson, and Sniderman [1992, 1993b]), we demonstrate that lenders are quite heterogeneous in terms of the propensities to attract and approve minority applicants, and that there appears to be little consistency either within or between lenders in their actions toward minorities. Theories regarding the operation of housing credit markets should exploit these findings as part of a general explanation of the process generating the data.

Future studies of the relationship between race and risk outcomes would also appear to be particularly important in order to shed light on the reasons for observed racial differences in our residuals. If the patterns we observe are due to discrimination by lenders, and such discrimination takes the form of a higher risk threshold for minorities, then we would expect loans granted to black applicants to perform better 
than those granted to whites, ceteris paribus. Given the findings of this study, such examinations would seem very important. At the same time, we are cautious about the power of such hypothesis tests. Several different explanations for significant racial intercepts can be observationally equivalent, making it very difficult to claim persuasively that any one process adequately accounts for the variations in the data. Accordingly, careful attention to distinguishing among competing hypotheses through choice of data and modeling strategies seems especially important. 


\section{ENDNOTES}

1. See, for example, the Fair Housing Act of 1968 and the Equal Credit Opportunity Act of 1975, which prohibit lenders from discriminating against individual loan applicants on the basis of race or ethnic origin, gender, and other factors. The latter law also prohibits the explicit use of such variables in credit screening, even if cost-related. Also, the Community Reinvestment Act of 1977 requires that depository institutions help meet the credit needs of their communities, including low-income and minority areas, in a manner consistent with safe and sound banking.

2. Canner (1981), Avery and Buynak (1981), Avery and Canner (1983), and Bradbury, Case, and Dunham (1989) contrast the differences in mortgage credit originations between predominantly white and predominantly minority neighborhoods in various MSAs. These studies use either pre-1990 HMDA data or lien title data to infer from the neighborhoods' characteristics whether mortgage lenders treat neighborhoods differently depending on their racial composition. Calem (1992) contrasts the experiences of individual lenders participating in a Philadelphia area mortgage-lending plan with those who did not participate. His paper does document the existence of lender differences in the penetration of minority communities, but the primary focus is on the characteristics of the voluntary mortgage plan operated by a group of lenders. Avery (1989) notes the differences between studies based on lending in a neighborhood and the lending procedures adopted by individual lenders.

3. Two exceptions are King (1980) and Schafer and Ladd (1981), which find little evidence of neighborhood redlining but some evidence of higher denial rates for black and Hispanic applicants, after controlling for all available information on other factors, such as income and credit history, relevant to the lending decision. While quite informative, these studies are limited in their geographic coverage and in the number and types of lenders surveyed. In addition, there have been several studies that use household-level data without neighborhood effects. Canner, Gabriel, and Wooley (1991), Gabriel and Rosenthal (1991), and Duca and Rosenthal (1992) study racial aspects of credit rationing and market performance by using data from the Survey of Consumer Finances, which comprises information collected from a sample of households. These studies attempt to infer from the households' experiences and demographic characteristics whether lenders treat people differently as a result of their racial status. Canner and Luckett (1991) do not consider race, but do discuss factors associated with consumer and mortgage debt payment problems.

4. The model was actually estimated using deviations about the means, which is computationally equivalent to adding intercepts. For the new purchase sample, the $1,984,688$ observations were located in 607,631 unique combinations of the 40,008 tracts and 20,695 lenders in the sample spread across 340 MSAs; thus, the average tract had about 15 lenders, each of whom served about 30 tracts per MSA. For the refinancing sample, the 716,595 observations were located in 326,535 unique combinations of tracts and lenders. For the home improvement loan sample, the 787,951 observations were located in 267,158 unique combinations of tract and lender. 
5. Mortgage banks are considered to have an office in an MSA if they take five or more mortgage applications there. There is some evidence that a significant portion of applications to mortgage bankers, perhaps as high as 30 percent, may not have been reported in HMDA for 1990 and 1991 because firms fell below the $\$ 10$ million asset requirement. This may be particularly true for firms serving primarily as originators, selling loans in the secondary market. In November 1991, the Federal Reserve Board tightened the reporting requirements for mortgage banks, which should increase coverage.

6. Institutions with assets of less than $\$ 30$ million were not required to report race, income, and gender for loan applicants. In addition, the HMDA filings contained many errors and inconsistencies even after extensive editing by the receiving agencies. We dealt with missing and implausible data using a "hot deck" imputation procedure similar to that used by the U.S. Census Bureau. Applications with missing or implausible data were statistically matched to applications for the same type of loan in the same census tract that came closest to them in reported characteristics (race, loan action, income, and loan amount). Missing values were filled in using the variable value of the matched observation. Overall, income was imputed for 4.9 percent, loan amount for 1.5 percent, gender for 4.0 percent, and race for 5.6 percent of the study sample applications.

7. Applications were omitted from our sample for the following reasons: loans purchased from other institutions $(1,137,741)$ because they did not require an action by the reporting lender; applications for properties outside the MSAs in which the lender had an office $(1,523,429$ loans) because of inconsistent reporting requirements; applications for multifamily homes and those that never reached the stage of lender action because they were either withdrawn by the applicant or closed for incompleteness $(444,684)$.

8. The 8,745 financial institutions filing 1990 HMDA reports that had at least one loan in the study sample operated in an average of 2.7 MSAs. This translated into 23,248 study lenders when lenders were defined at the MSA level.

9. Household income of sample applicants may be higher than this figure, since the applicant's income used for mortgage qualification may not reflect all of the income received by the household.

10. The percent Hispanic in the HMDA sample is slightly higher than the overall U.S. population, due in part to the inclusion of Puerto Rico, and the percent black is slightly lower. U.S. figures are taken from the whole 1990 Census, which may differ somewhat from the coverage of the study sample, in that rural areas are included.

11. The reported standard errors in tables 3,4 , and 5 are those from a standard regression program. These may be biased due to heteroskedasticity stemming from the fact that the underlying model is a linear probability model.

12. See Lang and Nakamura (1993) for more discussion on this point. 


\section{REFERENCES}

Avery, Robert B. 1989. "Making Judgments about Mortgage Lending Patterns." Economic Commentary, Federal Reserve Bank of Cleveland (December 15).

Avery, Robert B., Patricia E. Beeson, and Mark S. Sniderman. 1992. "Cross-Lender Variation in Home Mortgage Lending." Working Paper 9219, Federal Reserve Bank of Cleveland (December).

1993a. "Home Mortgage Lending by the Numbers." Economic Commentary, Federal Reserve Bank of Cleveland (February 15).

1993b. "Lender Consistency in Housing Credit Markets." Proceedings, Conference on Bank Structure, Federal Reserve Bank of Chicago, forthcoming.

Avery, Robert B., and Thomas M. Buynak. 1981. "Mortgage Redlining: Some New Evidence." Economic Review, Federal Reserve Bank of Cleveland (Summer), pp. 18-32.

Avery, Robert B., and Glenn B. Canner. 1983. "Mortgage Redlining: A Multicity CrossSection Analysis." Unpublished Working Paper, Board of Governors of the Federal Reserve System, Washington, D.C.

Bradbury, Katharine, Karl E. Case, and Constance R. Dunham. 1989. "Geographic Patterns of Mortgage Lending in Boston, 1982-1987." New England Economic Review (September/October), pp. 3-30.

Calem, Paul S. 1992. "The Delaware Valley Mortgage Plan: An Analysis Using HMDA Data." Working Paper 92-3, Federal Reserve Bank of Philadelphia (February).

Canner, Glenn B. 1981. "Redlining and Mortgage Lending Patterns." In Research in Urban Economics, edited by J. Vernon Henderson, Greenwich, CT: JAI Press, pp. 67101.

Canner, Glenn B., Stuart A. Gabriel, and J. Michael Wooley. 1991. "Race, Default Risk, and Mortgage Lending: A Study of the FHA and Conventional Loan Markets." Southern Economic Journal, vol. 58 (no. 1), pp. 249-262.

Canner, Glenn B., and Charles A. Luckett. 1991. "Payment of Household Debts." Federal Reserve Bulletin, vol. 77 (April), pp. 218-229.

Canner, Glenn B., and Delores S. Smith. 1991. "Home Mortgage Disclosure Act: Expanded Data on Residential Lending." Federal Reserve Bulletin, vol. 77 (Noveinber), pp. 859-881. 
1992. "Expanded HMDA Data on Residential Lending: One Year Later." Federal Reserve Bulletin, vol. 78 (November), pp. 801-824.

Duca, John V., and Stuart S. Rosenthal. 1992. "Borrowing Constraints, Household Debt, and Racial Discrimination in Loan Markets." Unpublished manuscript.

Gabriel, Stuart A, and Stuart S. Rosenthal. 1991. "Credit Rationing, Race, and the Mortgage Market." Journal of Urban Economics, vol. 29 (May), pp. 371-379.

ICF, Incorporated. 1991. "The Secondary Market and Community Lending Through Lenders' Eyes." Paper prepared for the Federal Home Loan Mortgage Corporation (February).

King, A. Thomas. 1980. "Discrimination in Mortgage Lending: A Study of Three Cities." Working Paper No. 91, Office of Policy and Economic Research, Federal Home Loan Bank Board (February).

Lang, William W., and Leonard I. Nakamura. 1993. "A Model of Redlining." Journal of Urban Economics, vol. 33 (March), pp. 223-234.

Munnell, Alicia H., Lynne E. Browne, James McEnearney, and Geoffrey M. B. Tootell. 1992. "Mortgage Lending in Boston: Interpreting HMDA Data." Working Paper Series 92-7, Federal Reserve Bank of Boston (October).

Shafer, Robert, and Helen F. Ladd. 1981. Discrimination in Mortgage Lending. Cambridge, MA: MIT Press. 
Table 1: Characteristics of Mongage Applications, National Sample, 1990 HMDA

\begin{tabular}{|c|c|c|c|c|c|c|c|c|c|}
\hline \multirow[b]{2}{*}{ Race of Applicant } & $\begin{array}{l}\frac{\mathrm{Hol}}{\mathrm{H}} \\
\text { Percent P } \\
\text { Sample }\end{array}$ & $\begin{array}{l}\text { ame Punc } \\
\text { Percent I } \\
\text { Loans }\end{array}$ & $\begin{array}{l}\text { chase } \\
\text { Denial } \\
\text { Rate }\end{array}$ & $\begin{array}{c}\text { Percent } \\
\text { Sample }\end{array}$ & $\begin{array}{l}\text { Refinat } \\
\text { t Percent } \\
\text { e Loans }\end{array}$ & $\begin{array}{l}\text { nce } \\
\text { Denial } \\
\text { Rate }\end{array}$ & $\begin{array}{c}\text { Home } \\
\text { Percent P } \\
\text { Sample }\end{array}$ & $\begin{array}{l}\text { e. Improy } \\
\text { Percent } \\
\text { Loans }\end{array}$ & $\begin{array}{l}\text { yement } \\
\text { Denial } \\
\text { Rare }\end{array}$ \\
\hline & & & & & & & & & \\
\hline Native American & $0.6 \%$ & $0.6 \%$ & $19.3 \%$ & $0.6 \%$ & $0.6 \%$ & $21.2 \%$ & $0.9 \%$ & $1.0 \%$ & $22.7 \%$ \\
\hline Asian (or Pacific Islander) & 4.6 & 6.8 & 14.4 & 4.9 & 7.2 & 21.3 & 2.5 & 5.4 & 27.7 \\
\hline Black & 6.2 & 4.8 & 29.4 & 5.1 & 3.9 & 28.8 & 10.3 & 5.9 & 43.4 \\
\hline Hispanic & 6.6 & 6.4 & 22.1 & 7.7 & 7.3 & 25.6 & 5.7 & 5.4 & 35.4 \\
\hline White & 81.4 & 80.5 & 13.1 & 80.9 & 79.9 & 16.4 & 79.98 & 81.3 & 20.3 \\
\hline Other & 0.7 & 1.0 & 19.8 & 0.7 & 1.0 & 26.8 & 0.8 & 1.0 & 35.4 \\
\hline \multicolumn{10}{|l|}{ Race of Co-applicant } \\
\hline No Co-applicant & 28.4 & 24.1 & 17.3 & 24.8 & 23.8 & 21.0 & 33.52 & 26.3 & 29.8 \\
\hline Same Race as Applicant & 69.4 & 73.4 & 13.8 & 73.2 & 73.9 & 17.1 & 64.9 & 71.6 & 20.8 \\
\hline Different Race than Applicant & 2.2 & 2.5 & 15.6 & 2.0 & 2.3 & 19.4 & 1.6 & 2.1 & 21.1 \\
\hline \multicolumn{10}{|l|}{ Gender } \\
\hline Male Applicant, Female Co-applicant & 64.0 & 68.2 & 13.4 & 67.7 & 69.2 & 16.8 & 58.0 & 65.8 & 19.7 \\
\hline Female Applicant, Male Co-applicant & 4.3 & 4.2 & 18.6 & 4.9 & 4.2 & 21.4 & 6.9 & 6.1 & 28.6 \\
\hline Male Applicant and Co-applicant & 2.0 & 2.3 & 16.4 & 1.6 & 2.0 & 19.6 & 0.8 & 1.0 & 27.8 \\
\hline Female Applicant and Co-applicant & 1.2 & 1.2 & 18.1 & 0.9 & 0.8 & 20.2 & 0.8 & 0.8 & 28.1 \\
\hline Single Male Applicant & 16.9 & 15.6 & 17.9 & 14.7 & 15.7 & 22.0 & 19.5 & 16.3 & 29.5 \\
\hline Single Female Applicant & 11.5 & 8.5 & 16.5 & 10.1 & 8.1 & 19.6 & 14.0 & 9.9 & 30.1 \\
\hline Owner-Occupied & 93.6 & 94.5 & 14.9 & 90.9 & 91.5 & 18.1 & 97.25 & 96.1 & 23.8 \\
\hline \multicolumn{10}{|l|}{ Loan Type } \\
\hline Conventional & 75.1 & 82.9 & 14.9 & 96.4 & 98.2 & 17.9 & $96.0 \mathrm{~s}$ & 97.6 & 23.8 \\
\hline FHA & 20.4 & 13.7 & 14.5 & 2.9 & 1.4 & 23.0 & 3.9 & 2.1 & 24.2 \\
\hline VA & 4.5 & 3.4 & 15.8 & 0.7 & 0.4 & 21.3 & 0.1 & 0.3 & 22.0 \\
\hline FmHA & 0.0 & 0.02 & 2.0 & 0.0 & 0.0 & 22.5 & 0.0 & 0.0 & 28.2 \\
\hline \multicolumn{10}{|l|}{ Lender Action } \\
\hline Loan Denied & 14.8 & 13.1 & & 18.1 & 20.6 & & 23.8 & 20.2 & \\
\hline Loan Accepted and Withdrawn & 2.9 & 3.5 & & 4.1 & 5.4 & & 3.3 & 3.7 & \\
\hline Laan Originated & 82.3 & 83.4 & & 77.8 & 74.0 & & 72.8 & 76.1 & \\
\hline Loan Kept by Originator (\% of originations) & 44.9 & 47.7 & & 60.3 & 61.3 & & 93.08 & 85.2 & \\
\hline Loan Sold to FNMA (\% of originations) & 14.5 & 14.4 & & 13.4 & 11.8 & & 2.0 & 4.7 & \\
\hline Loan Sold to GNMA ( $\%$ of originations) & 10.5 & 7.6 & & 1.8 & 1.2 & & 0.2 & 0.5 & \\
\hline Loan Sold to FHLMC (\% of originations) & 9.0 & 9.1 & & 10.8 & 9.7 & & 0.9 & 2.6 & \\
\hline Loan Sold Elsewhere ( $\%$ of originations) & 21.1 & 21.2 & & 10.6 & 16.0 & & 3.9 & 7.0 & \\
\hline \multicolumn{10}{|l|}{ Reasons for Denial (of Loans Denied) ${ }^{1}$} \\
\hline No Reason Given & 32.0 & 29.5 & & 26.7 & 25.8 & & 36.2 & 42.6 & \\
\hline Debt-to-Income Ratio & 16.0 & 17.7 & & 17.8 & 17.2 & & 20.2 & 16.9 & \\
\hline Employment History & 4.2 & 3.1 & & 2.3 & 1.8 & & 2.4 & 1.9 & \\
\hline Credit History & 26.0 & 22.1 & & 25.3 & 22.1 & & 29.7 & 19.5 & \\
\hline Collateral & 8.2 & 8.9 & & 14.3 & 16.4 & & 9.2 & 9.3 & \\
\hline Insufficient Cash & 4.0 & 4.1 & & 1.6 & 1.9 & & 0.8 & 1.0 & \\
\hline Unverifiable Information & 2.8 & 3.8 & & 3.7 & 4.5 & & 1.5 & 1.8 & \\
\hline Application Incomplete & 2.6 & 3.7 & & 2.9 & 3.5 & & 1.4 & 1.8 & \\
\hline Mortgage Insurance Denied & 0.6 & 0.7 & & 0.2 & 0.2 & & 0.2 & 0.2 & \\
\hline Other & 14.8 & 17.8 & & 17.6 & 18.7 & & 9.81 & 14.1 & \\
\hline \multicolumn{10}{|l|}{ Memo ltems: } \\
\hline Median Income $(\$ 1,000 s)$ & & $\$ 48$ & & & $\$ 56$ & & & $\$ 39$ & \\
\hline Median Loan Request $(\$ 1,000$ s) & & $\$ 77$ & & & $\$ 83$ & & & $\$ 10$ & \\
\hline Number of Loans & & 984,688 & & & 716,595 & & & 787,95 & \\
\hline
\end{tabular}

\footnotetext{
${ }^{1}$ Up to three reasons for denial could be given, and answers were voluntary. Each category gives the percent of all denials that gave that reason as one of the three.
}

SOURCE FOR ALL TABLES: Authors. 
Table 2: Characteristics of Mortgage Applications by Race, National Sample, 1990 HMDA

\begin{tabular}{|c|c|c|c|c|c|c|c|c|c|}
\hline \multirow{2}{*}{ Gender } & \multicolumn{3}{|c|}{$\frac{\text { Home Purchase }}{\text { Black Hispanic White }}$} & \multicolumn{3}{|c|}{$\frac{\text { Refinance }}{\text { Black Hispanic White }}$} & \multicolumn{3}{|c|}{$\begin{array}{l}\text { Home Improvement } \\
\text { Black Hispanic White }\end{array}$} \\
\hline & & & & & & & & & \\
\hline Two Applicants & $58.0 \%$ & $80.0 \%$ & 71.7\% & $64.6 \%$ & $80.8 \%$ & $75.2 \%$ & $47.8 \%$ & $71.2 \%$ & $68.2 \%$ \\
\hline Single Male Applicant & 19.8 & 12.7 & 17.1 & 16.2 & 11.0 & 15.1 & 24.4 & 17.3 & 19.1 \\
\hline Single Female Applicant & 22.2 & 7.3 & 11.2 & 19.2 & 8.3 & 9.7 & 27.8 & 11.5 & 12.7 \\
\hline Owner-Occupied & 94.5 & 93.6 & 93.7 & 88.0 & 90.4 & 91.2 & 96.6 & 96.5 & 97.3 \\
\hline \multicolumn{10}{|l|}{ Loan Type } \\
\hline Conventional & 52.1 & 72.9 & 76.0 & 92.7 & 96.4 & 96.5 & 93.4 & 92.1 & 96.6 \\
\hline FHA & 38.2 & 24.1 & 19.5 & 5.6 & 3.2 & 2.8 & 6.5 & 7.8 & 3.2 \\
\hline VA & 9.7 & 2.9 & 4.5 & 1.7 & 0.4 & 0.7 & 0.1 & 0.2 & 0.1 \\
\hline \multicolumn{10}{|l|}{ Lender Action } \\
\hline Loan Denied & 29.4 & 22.1 & 13.1 & 28.8 & 25.6 & 16.4 & 43.4 & 35.4 & 20.3 \\
\hline Laan Accepted and Withdrawn & 3.1 & 3.8 & 2.8 & 8.3 & 6.7 & 3.4 & 3.4 & 4.4 & 3.2 \\
\hline Laan Originated & 67.6 & 74.1 & 84.2 & 62.9 & 67.7 & 80.1 & 53.3 & 60.2 & 76.5 \\
\hline Loan Kept by Originator (\% of originations) & 35.9 & 47.1 & 45.1 & 56.2 & 51.2 & 61.7 & 94.5 & 91.4 & 93.1 \\
\hline Loan Sold to FNMA (\% of originations) & 9.9 & 10.0 & 14.9 & 11.9 & 12.6 & 13.4 & 1.5 & 1.9 & 2.0 \\
\hline Loan Sold to GNMA (\% of originations) & 20.5 & 11.9 & 10.2 & 3.8 & 1.9 & 1.7 & 0.4 & 0.3 & 0.2 \\
\hline Loan Sold to FHLMC (\% of originations) & 6.4 & 13.4 & 8.5 & 10.7 & 19.2 & 10.0 & 0.8 & 1.9 & 0.7 \\
\hline Loan Sold Elsewhere (\% of originations) & 27.4 & 17.5 & 21.3 & 17.4 & 15.1 & 13.2 & 2.8 & 4.5 & 3.9 \\
\hline \multicolumn{10}{|l|}{ Reasons for Denial (of Loans Denied) ${ }^{3}$} \\
\hline No Reason Given & 30.4 & 33.1 & 32.0 & 31.0 & 23.8 & 26.4 & 28.0 & 47.3 & 35.9 \\
\hline Debt-to-Income Ratio & 13.5 & 15.9 & 16.3 & 15.4 & 17.1 & 18.3 & 21.2 & 16.8 & 20.6 \\
\hline Employment History & 3.4 & 3.4 & 4.5 & 1.5 & 2.0 & 2.4 & 2.0 & 1.9 & 2.6 \\
\hline Credit History & 37.9 & 24.2 & 25.1 & 31.8 & 28.0 & 25.0 & 40.9 & 23.5 & 28.3 \\
\hline Collateral & 5.7 & 9.3 & 8.4 & 12.0 & 16.4 & 14.2 & 9.1 & 6.9 & 9.8 \\
\hline Insufficient Cash & 3.9 & 4.1 & 4.1 & 1.2 & 1.3 & 1.7 & 0.5 & 0.7 & 0.9 \\
\hline Unverifiable Information & 2.1 & 4.1 & 2.6 & 2.7 & 4.0 & 3.7 & 1.3 & 1.7 & 1.5 \\
\hline Application Incomplete & 2.4 & 3.4 & 2.6 & 2.3 & 3.2 & 2.9 & 1.6 & 1.1 & 1.4 \\
\hline Mortgage Insurance Denied & 0.5 & 0.6 & 0.7 & 0.2 & 0.2 & 0.3 & 0.2 & 0.1 & 0.2 \\
\hline Other & 11.1 & 14.8 & 15.1 & 14.4 & 17.9 & 17.6 & 8.3 & 10.1 & 10.1 \\
\hline \multicolumn{10}{|l|}{ Memo Items: } \\
\hline Median Income $(\$ 1,000 s)$ & $\$ 36$ & $\$ 44$ & $\$ 48$ & $\$ 47$ & $\$ 50$ & $\$ 56$ & $\$ 27$ & $\$ 35$ & $\$ 40$ \\
\hline Median Loan Request $(\$ 1,000 s)$ & $\$ 61$ & $\$ 85$ & $\$ 76$ & $\$ 71$ & $\$ 100$ & $\$ 79$ & $\$ 5$ & $\$ 11$ & $\$ 10$ \\
\hline
\end{tabular}

'Up to three reasons for denial could be given, and answers were voluntary. Each category gives the percent of all denials that gave that reason as one of the three. 
Table 3: Linear Probability Model of Loan Denial (1) or Acceptance (0), Home Purchase

\begin{tabular}{|c|c|c|}
\hline & Parameter Estimate & Standard Error \\
\hline \multicolumn{3}{|l|}{ Race (Dummies, "White" Is Base Group) } \\
\hline Black Applicant & $.10258^{* *}$ & .00403 \\
\hline Hispanic Applicant. & $.04018^{20}$ & .00392 \\
\hline Native American Applicant & $.02813^{\circ 00}$ & .00569 \\
\hline Asian Applicant & $.00801^{*}$ & .00390 \\
\hline Other Race Applicant & $.02987^{* \cdots}$ & .00364 \\
\hline Mixed Race, Minority Co-applicant (Dummy) & $.02410^{\circ \cdots}$ & .00337 \\
\hline Mixed Race, Nonminority Co-applicant (Dummy) & $-0.02690^{* \cdots}$ & .00329 \\
\hline Owner-occupied (Dunmy) & $.00630^{\circ \cdots}$ & .00132 \\
\hline \multicolumn{3}{|l|}{ Income $\left(\$ I, 000^{\circ} s\right)$} \\
\hline Income & $-0.00985^{\circ * 0}$ & .00034 \\
\hline Income Spline at $\$ 20,000$ & .00606 & .00038 \\
\hline Income Spline at $\$ 40,000$ & $.00282^{\cdots \cdots}$ & .00015 \\
\hline Income Spline at $\$ 60,000$ & $.00063^{000}$ & .00015 \\
\hline Income Spline at $\$ 80,000$ & .00016 & .00017 \\
\hline Income Spline at $\$ 100,000$ & .00011 & .00014 \\
\hline Income Spline at $\$ 150,000$ & -0.00004 & .00010 \\
\hline Income Spline at $\$ 200,000$ & .00010 & .00006 \\
\hline \multicolumn{3}{|l|}{ Loan Amount ( $\$ 1,000^{\prime}$ s) } \\
\hline Loan Amount & $-0.00193^{* 00}$ & .00020 \\
\hline Loan Amount Spline at $\$ 20,000$ & .00028 & .00027 \\
\hline Loan Amount Spline at $\$ 40,000$ & $.00179^{\cdots+*}$ & .00018 \\
\hline Loan Amount Spline at $\$ 60,000$ & -0.00018 & .00016 \\
\hline Loan Amount Spline at $\$ 80,000$ & $.00033^{\circ}$ & .00016 \\
\hline Loan Amount Spline at $\$ 100,000$ & -0.00015 & .00014 \\
\hline Loan Amount Spline at $\$ 125,000$ & .00012 & .00008 \\
\hline Loan Amount Spline at $\$ 200,000$ & $-0.00021^{\cdots \cdots}$ & .00003 \\
\hline \multicolumn{3}{|c|}{ Loan-lo-Income Ratio (Dummies, Less than Is Is Base Group) } \\
\hline Ratio of 1.5 to 2.0 & $-0.01016^{* *}$ & .00105 \\
\hline Ratio of 2.0 to 2.25 & $-0.01168^{* \cdots}$ & .00141 \\
\hline Ratio of 2.25 to 2.5 & $-0.01195^{\circ \cdots}$ & .00163 \\
\hline Ratio of 2.5 to 2.75 & $-0.00737^{\cdots}$ & .00187 \\
\hline Ratio of 2.75 to 3.0 & .00323 & .00227 \\
\hline Ratio over 3.0 & $.05062^{\cdots}$ & .00207 \\
\hline \multicolumn{3}{|c|}{ Applicant Gender (Dummies, Female Applicant, No Co-applicant Is Base Group) } \\
\hline Male Applicant, Female Co-applicant & $-0.01886^{\circ}$ & .00763 \\
\hline Female Applicant, Male Co-applicant & -0.00766 & .00772 \\
\hline Male Applicant and Co-applicant & -0.00390 & .00787 \\
\hline Female Applicant and Co-applicant & -0.01021 & .00800 \\
\hline Male Applicant, No Co-applicant & $.02834^{\cdots \cdots}$ & .00109 \\
\hline \multicolumn{3}{|l|}{ Income, Interacted With No Co-applicant } \\
\hline Income & $-0.00334^{-\cdots}$ & .00042 \\
\hline Income Spline at $\$ 20,000$ & $.00516 \%$ & .00049 \\
\hline Income Spline at $\$ 40,000$ & $-0.00051^{\circ}$ & .00024 \\
\hline Income Spline at $\$ 60,000$ & $-0.00137^{\circ \cdots}$ & .00030 \\
\hline Income Spline at $\$ 80,000$ & .00048 & .00036 \\
\hline
\end{tabular}


Table 3: (continued)

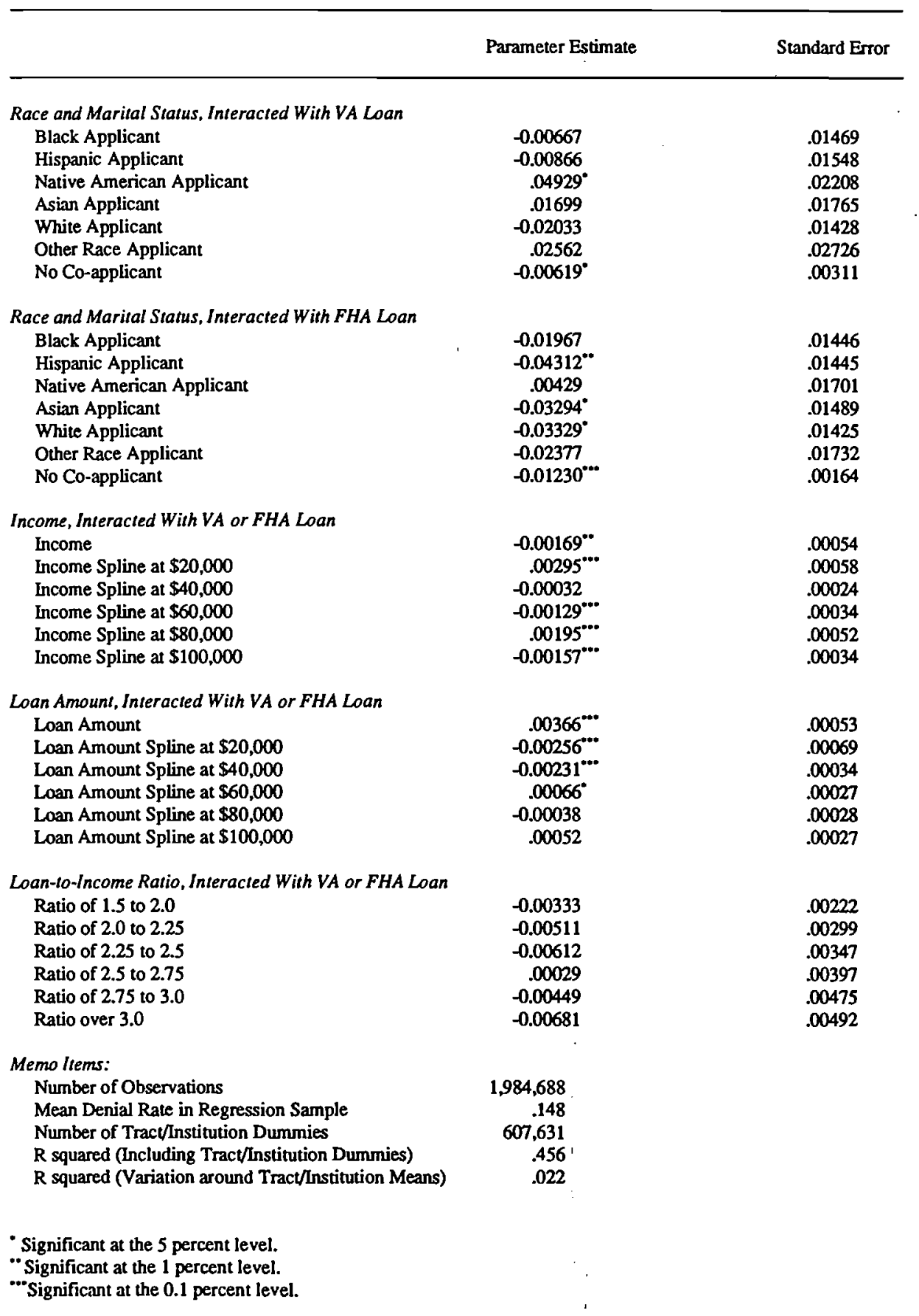




\begin{tabular}{|c|c|c|}
\hline & Parameter Estimate & Standard Error \\
\hline \multicolumn{3}{|l|}{ Race (Dummies, "Whire" Is Base Group) } \\
\hline Black Applicant & $.07044^{\cdots}$ & .00769 \\
\hline Hispanic Applicant & $.04841^{\circ \infty}$ & .00740 \\
\hline Native American Applicant & $.02556^{\circ}$ & .01042 \\
\hline Asian Applicant & $.03900^{\circ \cdots}$ & .00751 \\
\hline Other Race Applicant & $.03841^{\cdots \cdots}$ & .00703 \\
\hline $\begin{array}{l}\text { Mixed Race, Minority Co-applicant (Dummy) } \\
\text { Mixed Race, Nonminority Co-applicant (Dummy) }\end{array}$ & $\begin{array}{ll}.00576 \\
-0.02336^{\circ}\end{array}$ & $\begin{array}{l}.00700 \\
.00694\end{array}$ \\
\hline Owner-occupied (Dummy) & -0.00063 & 00223 \\
\hline VA Loan (Dummy) & -0.01573 & .00979 \\
\hline \multicolumn{3}{|l|}{ Income ( $\$ 1,000$ 's) } \\
\hline Income & .00136 & .00053 \\
\hline Income Spline at $\$ 20,000$ & $-0.00424^{-\cdots}$ & .00063 \\
\hline Income Spline at $\$ 40,000$ & $.00215^{\circ \cdots *}$ & .00028 \\
\hline Income Spline at $\$ 60,000$ & -0.00007 & .00027 \\
\hline Income Spline at $\$ 80,000$ & $.00116^{\ldots-*}$ & .00031 \\
\hline Income Spline at $\$ 100,000$ & -0.00036 & .00024 \\
\hline Income Spline at $\$ 150,000$ & .00015 & .00016 \\
\hline Income Spline at $\$ 200,000$ & -0.00016 & .00009 \\
\hline \multicolumn{3}{|l|}{ Loan Amount ( $\$ 1,000$ 's) } \\
\hline Loan Amount & $-0.00341^{\circ \cdots *}$ & .00030 \\
\hline Loan Amount Spline at $\$ 20,000$ & $.00285^{\circ \cdots}$ & .00042 \\
\hline Loan Amount Spline at $\$ 40,000$ & .00079 & .00030 \\
\hline Loan Amount Spline at $\$ 60,000$ & .00014 & .00031 \\
\hline Loan Amount Spline at $\$ 80,000$ & -0.00010 & .00032 \\
\hline Loan Amount Spline at $\$ 100,000$ & .00003 & .00027 \\
\hline Loan Amount Spline at $\$ 125,000$ & $.00036^{\circ}$ & .00015 \\
\hline Loan Amount Spline at $\$ 200,000$ & $-0.00055^{\circ \cdots}$ & .00004 \\
\hline \multicolumn{3}{|c|}{ Loan-to-Income Ratio (Dummies, Less than IS Is Base Group) } \\
\hline Ratio of 1.5 to 2.0 & -0.00218 & .00200 \\
\hline Ratio of 2.0 to 2.25 & .00451 & .00266 \\
\hline Ratio of 2.25 to 2.5 & $.00700^{\circ}$ & .00301 \\
\hline Ratio of 2.5 to 2.75 & $.01506^{\circ * *}$ & .00324 \\
\hline Ratio of 2.75 to 3.0 & $.02567^{\cdots \cdots}$ & .00375 \\
\hline Ratio over 3.0 & $.08614^{\cdots \cdots}$ & .00326 \\
\hline \multicolumn{3}{|c|}{ Applicant Gender (Dummies, Female Applicant, No Co-applicant Is Base Group) } \\
\hline Male Applicant, Female Co-applicant & $-0.09269^{\circ \cdots}$ & .01395 \\
\hline Female Applicant, Male Co-applicant & $-0.08497^{* \cdots}$ & .01416 \\
\hline Male Applicant and Co-applicant & $-0.06650^{\circ \cdots *}$ & .01467 \\
\hline Female Applicant and Co-applicant & $-0.08148^{* * *}$ & .01513 \\
\hline Male Applicant, No Co-applicant & $.02477^{\cdots *}$ & .00251 \\
\hline
\end{tabular}


Table 4: (continued)

\begin{tabular}{|c|c|c|}
\hline & Parameter Esimate & Standard Error \\
\hline \multicolumn{3}{|l|}{ Income, Interacted With No Co-applicant } \\
\hline Income & $-0.00496^{\cdots}$ & .00080 \\
\hline Income Spline at $\$ 20.000$ & $.00494^{\cdots \cdots}$ & .00100 \\
\hline Income Spline at $\$ 40,000$ & .00077 & .00055 \\
\hline Income Spline at $\$ 60,000$ & -0.00011 & .00062 \\
\hline Income Spline at $\$ 80,000$ & -0.00063 & .00068 \\
\hline Income Spline at $\$ 100,000$ & -0.00001 & .00035 \\
\hline \multicolumn{3}{|l|}{ Interacted With VA or FHA Loan } \\
\hline Black Applicant & $.11374^{* \cdots}$ & .01851 \\
\hline Hispanic Applicant & $.06567^{* * *}$ & .01948 \\
\hline Native American Applicant & .06397 & .04933 \\
\hline Asian Applicant & .02391 & .02656 \\
\hline White Applicant & $.07913^{\cdots}$ & .01269 \\
\hline Other Race Applicant & .03883 & .05012 \\
\hline No Co-applicant & .00294 & .00836 \\
\hline Income & .00005 & .00009 \\
\hline Loan Amount & -0.00024 & .00015 \\
\hline \multicolumn{3}{|l|}{ Memo ltems: } \\
\hline Number of Observations & 716,595 & \\
\hline Mean Denial Rate in Regression Sample & .181 & \\
\hline Number of Tract/Institution Dummies & 326,535 & \\
\hline R squared (Including Tract/Institution Dummies) & 552 & \\
\hline R squared (Variation around Tract/Institution Means) & .020 & \\
\hline
\end{tabular}


Table 5: Linear Probability Model of Loan Denial (1) or Acceptance (0), Home Improvement

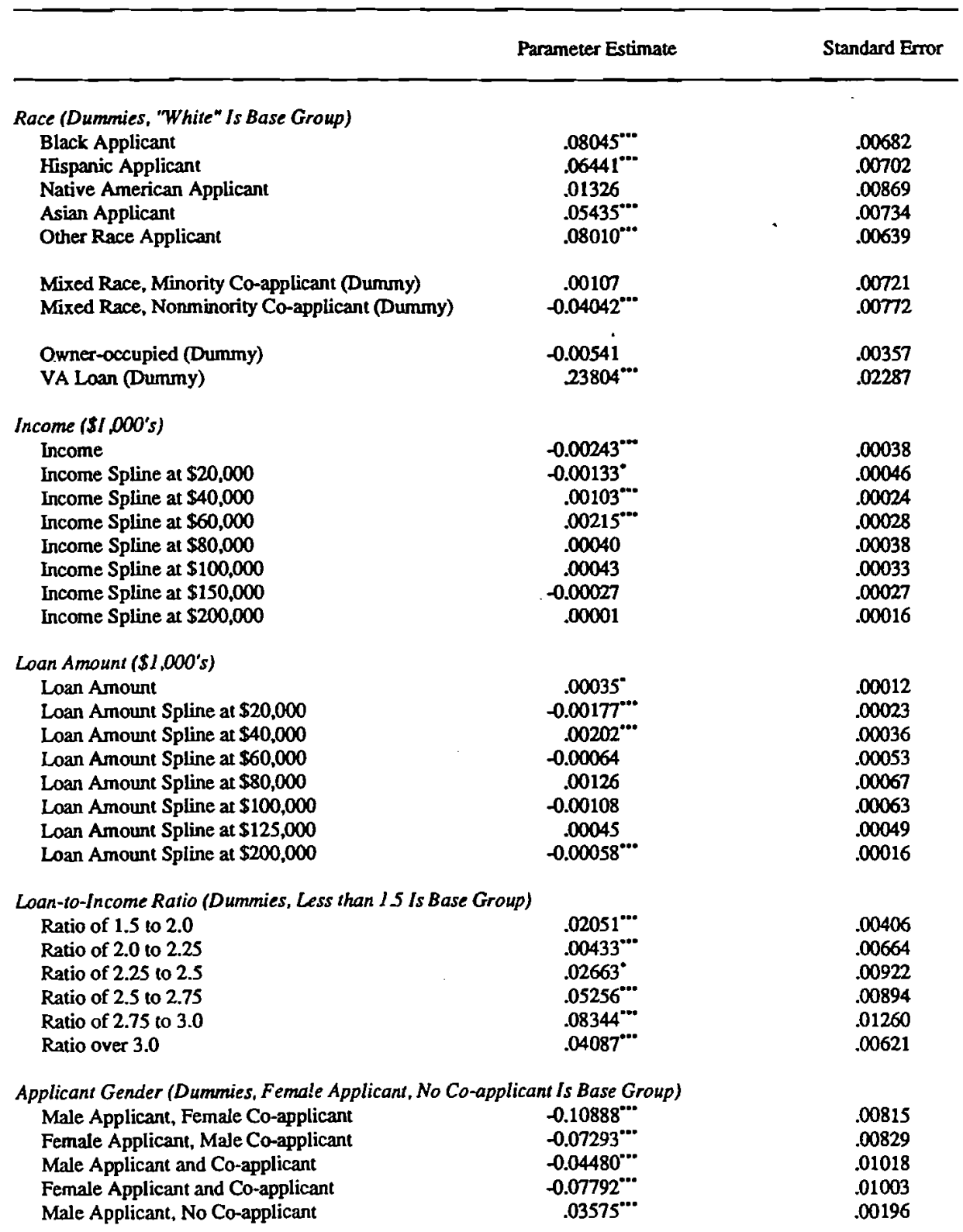


Table 5: (continued)

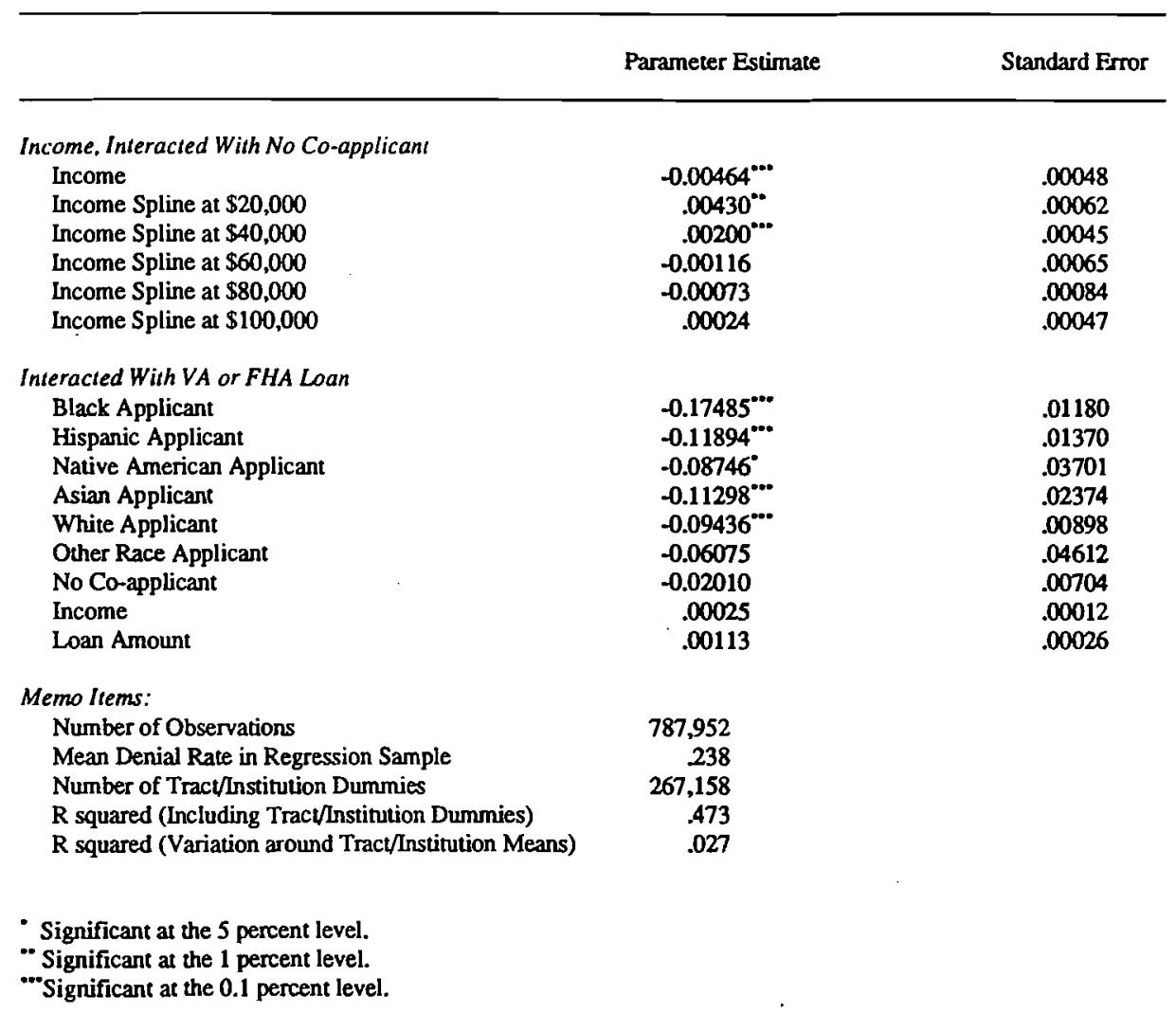


Table 6: Difference in Average Percentage Denial Rates Attributable to Various Sources. Home Purchase Loans, by Neighborhood and Race, 1990 HMDA

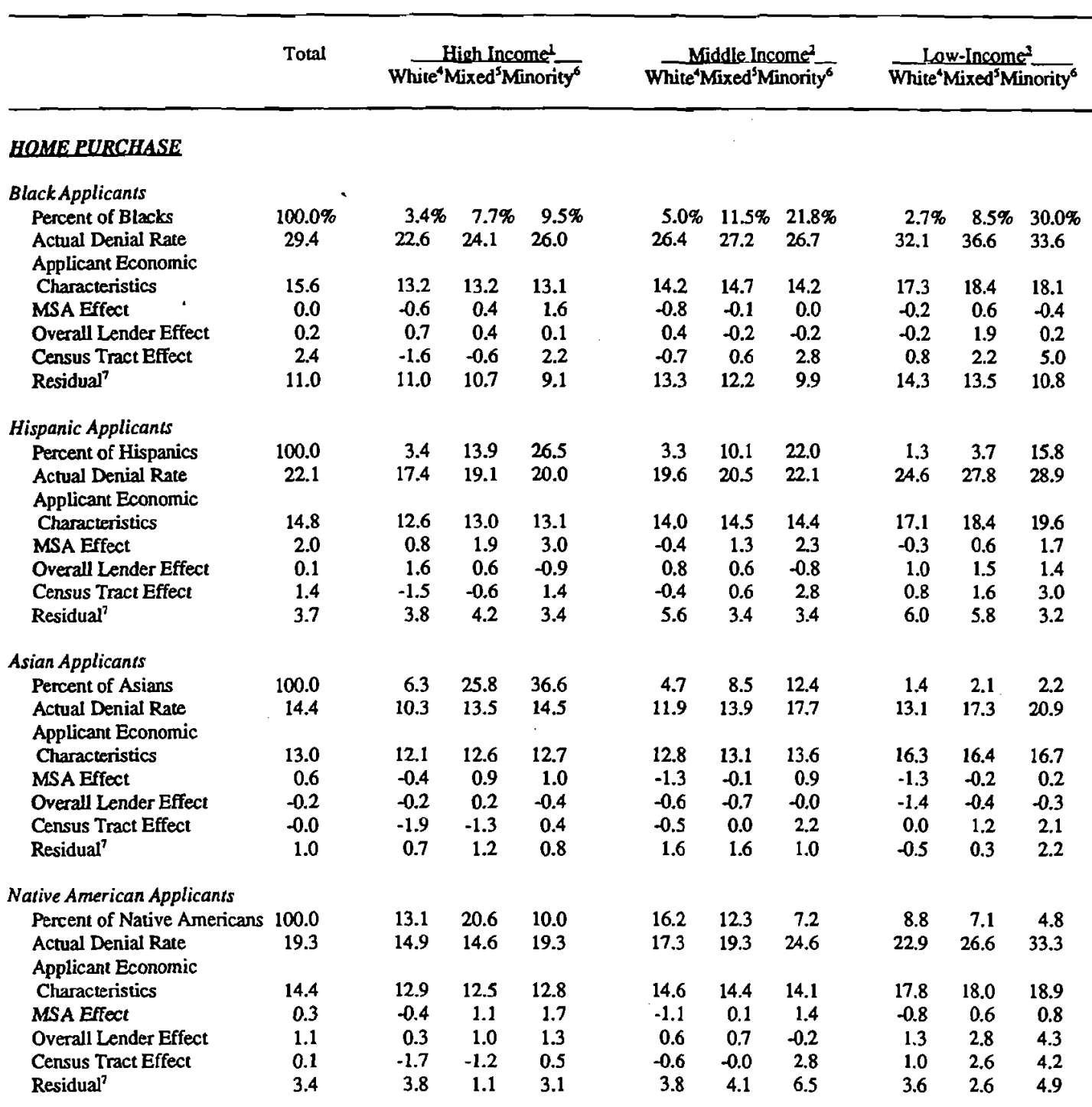




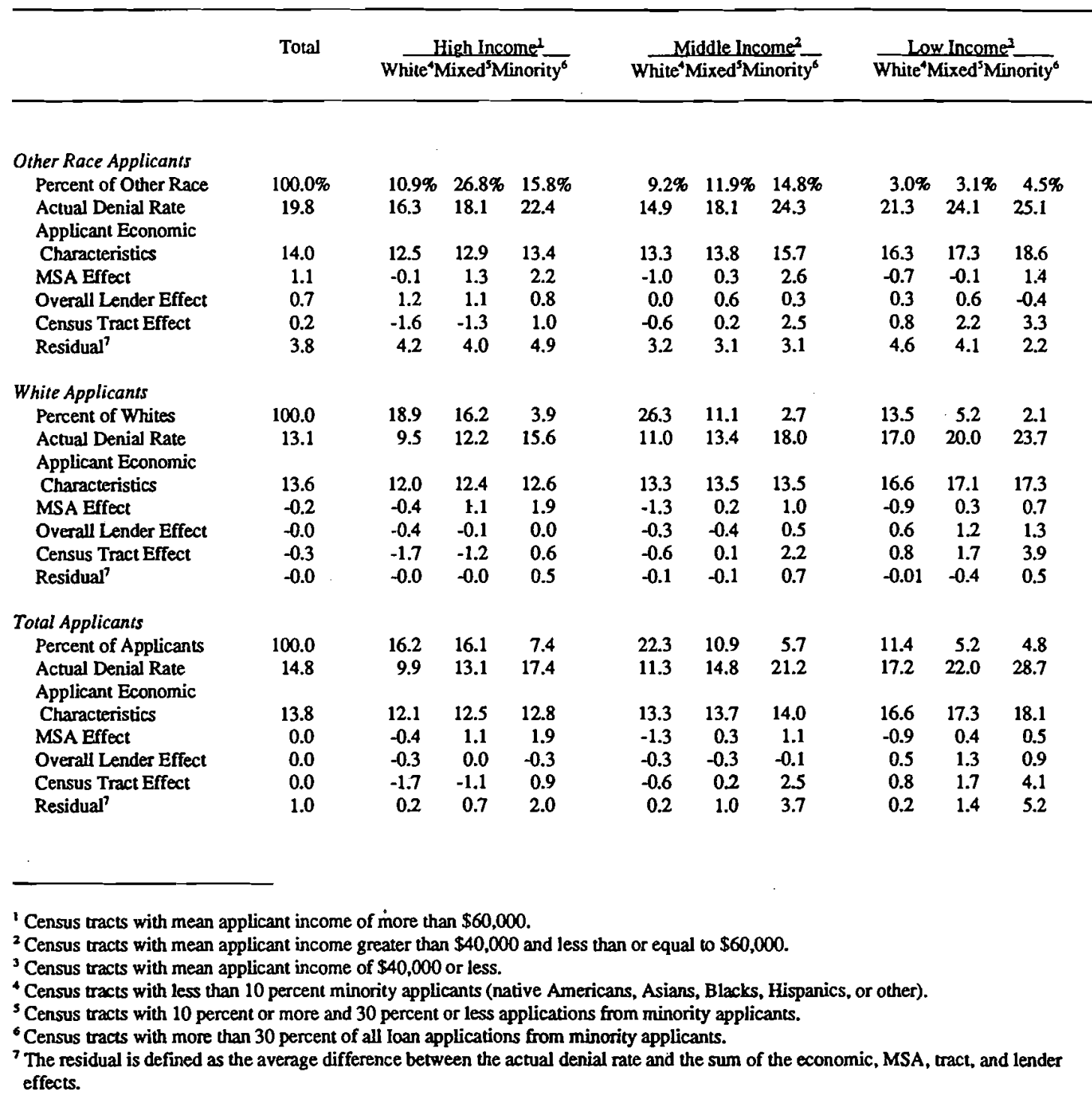


http://www.clevelandfed.org/Research/Workpaper/Index.cfm

Table 7: Difference in A verage Percentage Denial Rates Atuributable to Various Sources, Refinance Loans, by Neighborhood and Race, $1990 \mathrm{HMDA}$

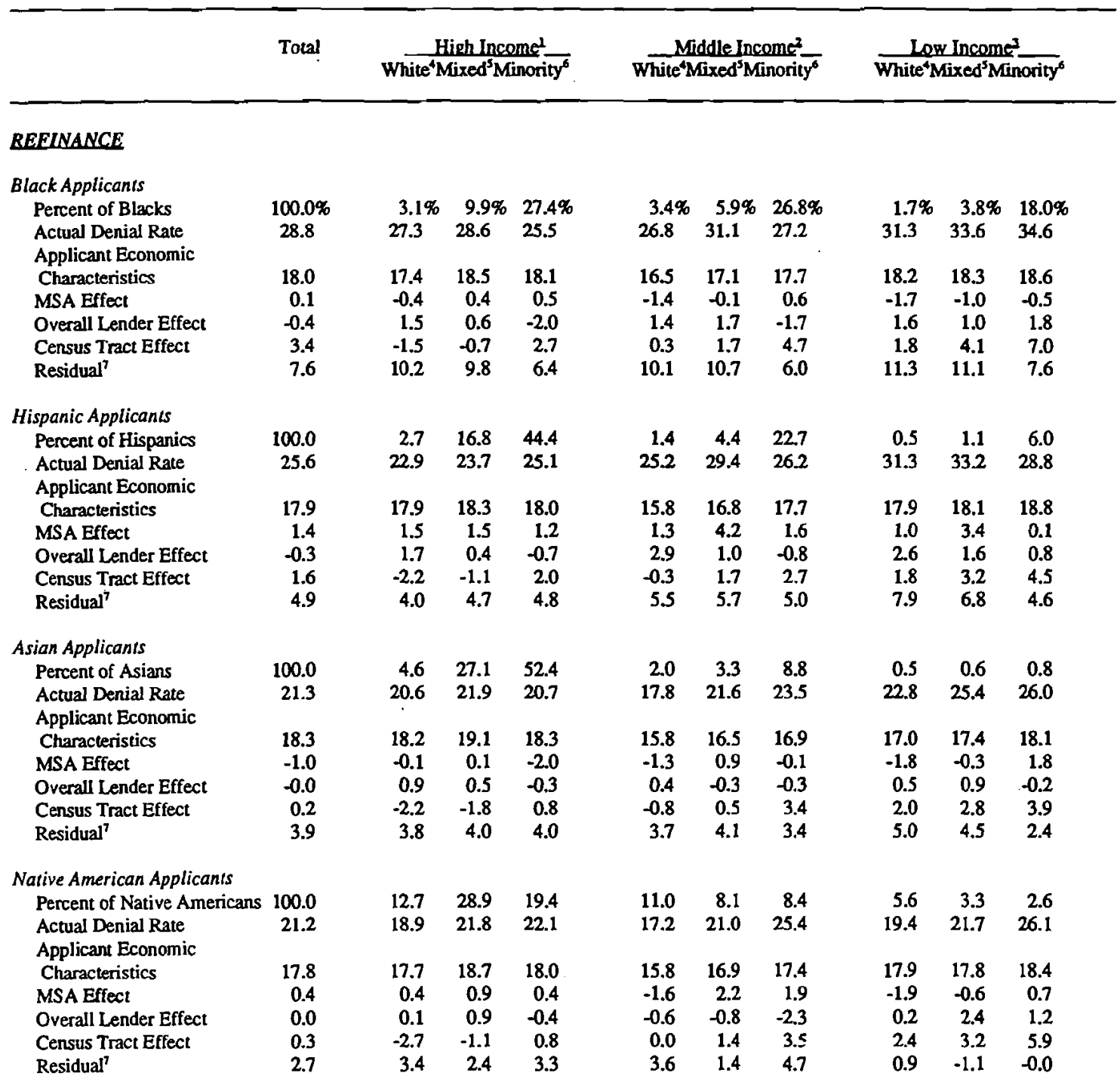


Table 7: (continued)

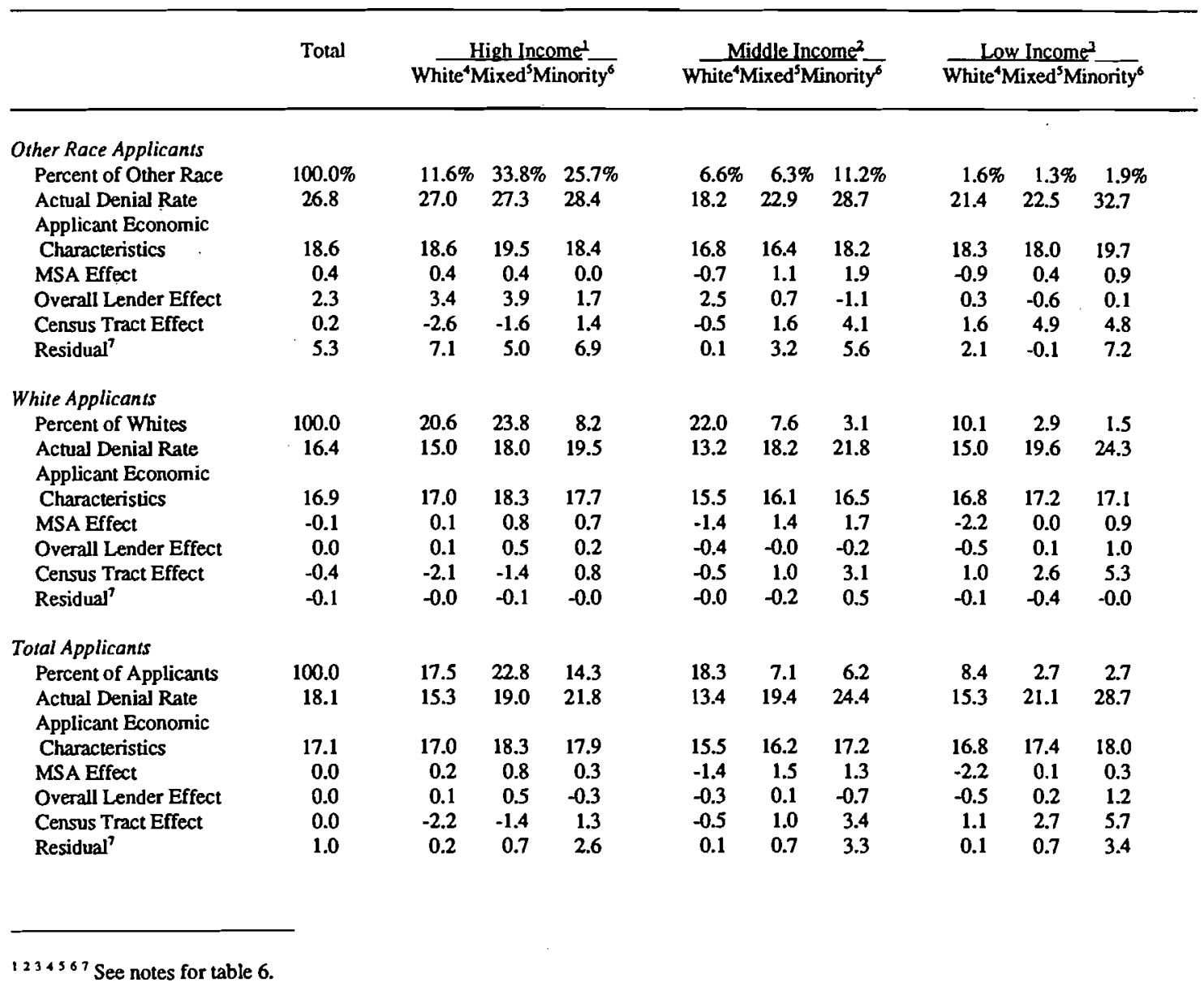


http://www.clevelandfed.org/Research/Workpaper/Index.cfm

Table 8: Difference in A verage Percentage Denial Rates Atributable to Various Sources, Home Improvement Loans, by Neighborhood and Race, 1990 HMDA

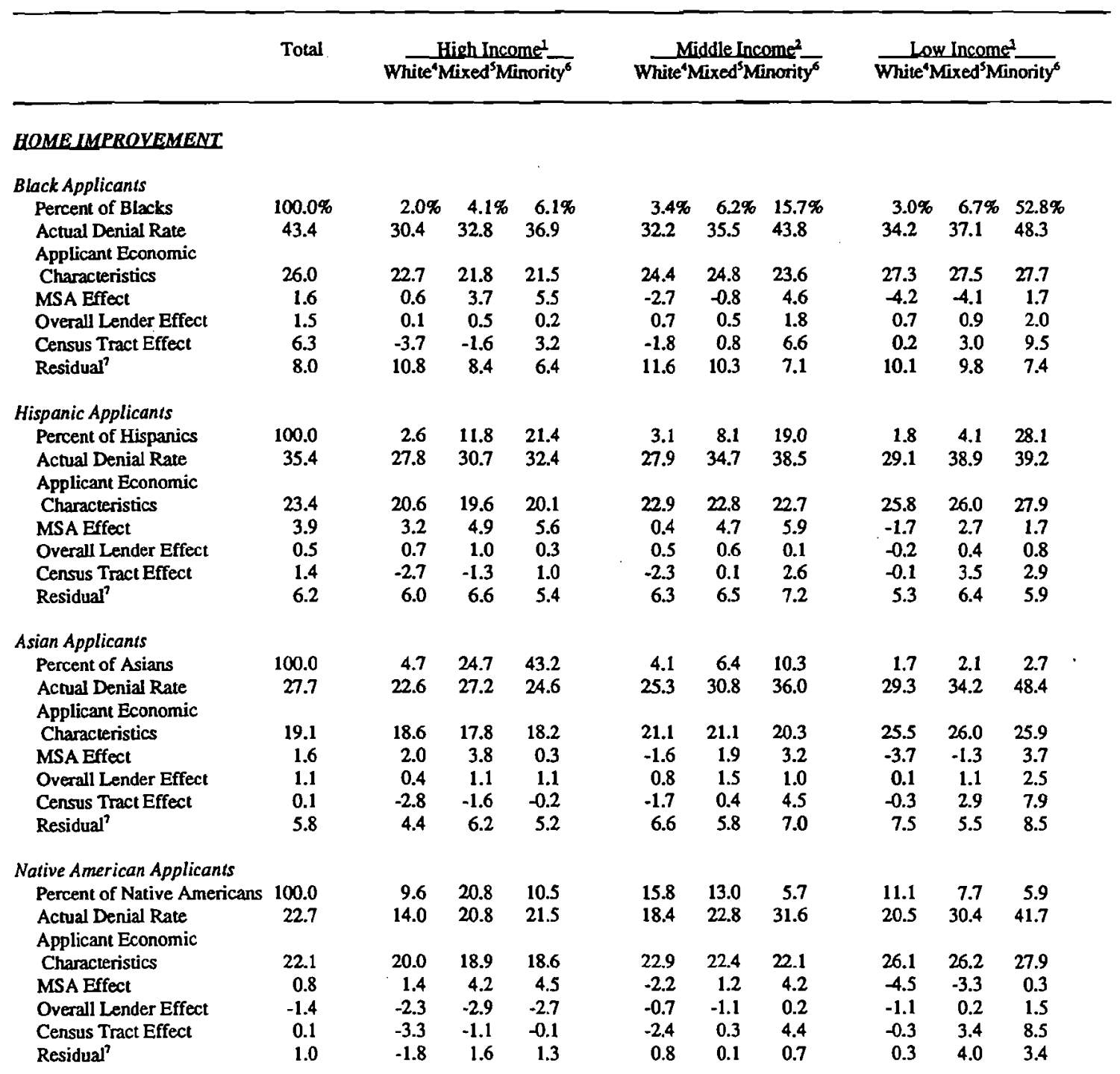


Table 8: (continued)

\begin{tabular}{|c|c|c|c|c|c|c|c|c|c|c|}
\hline \multirow{2}{*}{ Other Race Applicants } & \multirow[t]{2}{*}{ Total } & \multicolumn{3}{|c|}{$\frac{\text { High Incomed }}{\text { White }^{4} \text { Mixed }}$ Minority $^{6}$} & \multicolumn{3}{|c|}{$\frac{\text { Middle Income }^{2}}{\text { White }^{4} \text { Mixed }^{5} \text { Minority }^{6}}$} & \multicolumn{3}{|c|}{$\frac{\text { Low Income }}{\text { White }^{3} \text { Mixed }^{5} \text { Minority }^{6}}$} \\
\hline & & & & & & & & & & \\
\hline Percent of Other Race & $100.0 \%$ & $9.0 \%$ & $23.9 \%$ & $14.7 \%$ & $12.4 \%$ & $12.9 \%$ & $10.2 \%$ & $4.9 \%$ & $5.2 \%$ & $6.8 \%$ \\
\hline Acrual Denial Rate & 35.4 & 28.7 & 30.1 & 35.2 & 31.9 & 37.9 & 40.1 & 32.0 & 38.6 & 57.8 \\
\hline Characteristics & 21.9 & 20.2 & 19.3 & 19.2 & 23.1 & 23.3 & 22.6 & 25.4 & 26.8 & 27.6 \\
\hline MSA Effect . & 2.3 & 1.2 & 3.5 & 4.9 & -2.1 & 0.9 & 5.7 & -2.0 & 0.0 & 4.0 \\
\hline Overall Lender Effect & 2.9 & 2.5 & 2.1 & 2.0 & 3.7 & 4.4 & 1.9 & 2.0 & 4.0 & 4.5 \\
\hline Census Tract Effect & 0.4 & -3.4 & -2.2 & 0.8 & -1.2 & -0.2 & 4.7 & 0.1 & 3.6 & 9.5 \\
\hline Residual? & 7.9 & 8.3 & 7.3 & 8.3 & 8.5 & 9.6 & 5.2 & 6.5 & 4.1 & 12.2 \\
\hline \multicolumn{11}{|l|}{ White Applicants } \\
\hline Percent of Whites & 100.0 & 15.2 & 13.3 & 3.9 & 27.2 & 9.2 & 2.9 & 18.8 & 5.9 & 3.6 \\
\hline $\begin{array}{l}\text { Acrual Denial Rate } \\
\text { Applicant Economic }\end{array}$ & 20.3 & 16.4 & 20.5 & 24.8 & 16.5 & 23.1 & 31.7 & 19.3 & 26.2 & 38.5 \\
\hline Characteristics & 22.0 & 19.7 & 18.6 & 18.9 & 22.2 & 21.9 & 21.7 & 25.1 & 25.4 & 26.0 \\
\hline MSA Effect & -0.6 & 0.8 & .4 .1 & 4.6 & -2.7 & 1.6 & 4.9 & -4.8 & -2.0 & 1.6 \\
\hline Overall Lender Effect & -0.3 & -0.7 & -0.4 & -0.0 & -0.7 & -0.2 & 1.0 & -0.3 & 0.2 & 2.5 \\
\hline Census Tract Effect & -0.9 & -3.5 & -1.8 & 0.5 & -2.3 & -0.0 & 4.2 & -0.6 & 2.9 & 7.7 \\
\hline Residual ${ }^{7}$ & -0.0 & -0.0 & -0.0 & 0.8 & -0.1 & -0.2 & -0.0 & -0.0 & -0.3 & 0.6 \\
\hline \multicolumn{11}{|l|}{ Total Applicants } \\
\hline Percent of Appicants & 100.0 & 12.8 & 12.7 & 6.3 & 22.6 & 8.8 & 5.4 & 15.6 & 5.8 & 10.1 \\
\hline Actual Denial Rate & 23.8 & 16.9 & 21.9 & 27.6 & 17.0 & 24.9 & 37.0 & 19.7 & 28.2 & 44.1 \\
\hline \multicolumn{11}{|l|}{ Applicant Economic } \\
\hline Characteristics & 22.5 & 19.8 & 18.7 & 19.3 & 22.3 & 22.2 & 22.4 & 25.1 & 25.7 & 27.2 \\
\hline MSA Effect & 0.0 & 0.9 & 4.1 & 4.1 & -2.7 & 1.6 & 4.9 & -4.8 & -2.1 & 1.7 \\
\hline Overall Lender Effect & 0.0 & -0.7 & -0.2 & 0.3 & -0.6 & -0.0 & 1.1 & -0.3 & 0.3 & 2.0 \\
\hline Census Tract Effect & 0.0 & -3.5 & -1.8 & 0.8 & -2.3 & 0.1 & 4.6 & -0.6 & 2.9 & 7.9 \\
\hline Residual 7 & 1.4 & 0.3 & 1.0 & 3.1 & 0.2 & 1.1 & 4.0 & 0.2 & 1.3 & 5.3 \\
\hline
\end{tabular}


Table 9: Difference in Average Percentage Denial Rates Attributable to Various Sources, Center City, by Neighborhood and Race, 1990 HMDA

\begin{tabular}{|c|c|c|c|c|c|c|c|c|c|c|}
\hline \multirow[b]{2}{*}{ HOMEPURCHASE } & \multirow[t]{2}{*}{ Total } & \multicolumn{3}{|c|}{$\frac{\text { High Incomed }}{\text { White }{ }^{4} \text { Mixed }}$} & \multicolumn{3}{|c|}{$\frac{\text { Middle Income }}{\text { White }^{2} \text { Mixed }}$} & \multicolumn{3}{|c|}{$\frac{\text { Low Income }}{\text { White }^{4} \text { Mixed }}$} \\
\hline & & & & & & & & & . & \\
\hline \multicolumn{11}{|l|}{ Black Applicants } \\
\hline Percent of Blacks & $100.0 \%$ & $2.1 \%$ & $4.7 \%$ & $7.8 \%$ & $3.3 \%$ & $8.7 \%$ & $20.7 \%$ & $2.1 \%$ & $8.5 \%$ & $42.1 \%$ \\
\hline Actual Denial Rate & 31.2 & 26.2 & 28.3 & 28.8 & 27.0 & 28.1 & 29.5 & 30.6 & 33.7 & 33.5 \\
\hline Census Tract Effect & 3.1 & 1.9 & -0.2 & 3.3 & -1.2 & 0.9 & 3.3 & 0.8 & 2.5 & 4.7 \\
\hline Residual $^{7}$ & 13.4 & 11.0 & 12.5 & 9.7 & 14.0 & 12.3 & 10.1 & 14.3 & 12.9 & 10.7 \\
\hline \multicolumn{11}{|l|}{ Hispanic Applicants } \\
\hline Percent of Hispanics & 100.0 & 2.3 & 10.1 & 21.5 & 2.3 & 8.9 & 24.7 & 1.2 & 4.8 & 24.2 \\
\hline Actual Denial Rate & 23.8 & 17.6 & 21.0 & 21.8 & 20.2 & 20.7 & 23.4 & 24.6 & 26.9 & 28.6 \\
\hline Census Tract Effect & 2.2 & -1.8 & -0.5 & 2.8 & -0.8 & 0.6 & 3.1 & 0.7 & 1.6 & 3.2 \\
\hline Residual $^{7}$ & 3.8 & 3.9 & 5.4 & 3.4 & 6.1 & 3.8 & 3.6 & 6.8 & 5.0 & 3.1 \\
\hline \multicolumn{11}{|l|}{ White Applicants } \\
\hline Percent of Whites & 100.0 & 15.3 & 15.6 & 4.7 & 21.2 & 12.5 & 4.2 & 14.1 & 8.3 & 4.3 \\
\hline Actual Denial Rate & 13.9 & 9.8 & 13.1 & 16.6 & 10.6 & 13.5 & 18.2 & 16.3 & 19.5 & 24.0 \\
\hline Census Tract Effect & -0.1 & -1.9 & -1.0 & 1.5 & 1.1 & 0.2 & 2.7 & 0.6 & 1.8 & 3.8 \\
\hline Residual $^{7}$ & -0.0 & -0.1 & -0.2 & 0.3 & -0.1 & -0.1 & 0.5 & -0.1 & 0.3 & 0.8 \\
\hline BEFINANCE & . & & & & & & & & & \\
\hline \multicolumn{11}{|l|}{ Black Applicants } \\
\hline Percent of Blacks & 100.0 & 1.5 & 6.9 & 25.5 & 1.7 & 4.1 & 29.7 & 1.1 & 3.7 & 25.8 \\
\hline Actual Denial Rate & 29.6 & 28.7 & 29.7 & 25.6 & 24.6 & 35.8 & 26.9 & 34.1 & 35.4 & 34.9 \\
\hline Census Tract Effect & 4.2 & -1.8 & -0.9 & 3.3 & -0.3 & 2.4 & 4.4 & 2.5 & 4.4 & 7.3 \\
\hline Residual $^{7}$ & 7.5 & 11.6 & 11.4 & 6.2 & 8.5 & 13.6 & 6.0 & 11.3 & 11.1 & 7.4 \\
\hline \multicolumn{11}{|l|}{ Hispanic Applicants } \\
\hline Percent of Hispanics & 100.0 & 2.0 & 15.4 & 41.0 & 1.0 & 4.3 & 24.5 & 0.5 & 1.5 & 9.7 \\
\hline Actual Denial Rate & 26.1 & 25.8 & 22.9 & 25.2 & 31.3 & 29.9 & 26.8 & 29.8 & 31.6 & 29.6 \\
\hline Census Tract Effect & 2.6 & -2.6 & -1.1 & 3.5 & -0.3 & 1.4 & 2.9 & 1.2 & 2.6 & 5.3 \\
\hline Residual $^{7}$ & 4.8 & 6.2 & 4.0 & 4.4 & 8.6 & 6.2 & 5.4 & 5.6 & 6.5 & 4.8 \\
\hline \multicolumn{11}{|l|}{ White Applicants } \\
\hline Percent of Whites & 100.0 & 16.3 & 25.4 & 10.1 & 16.5 & 9.1 & 5.1 & 9.1 & 5.0 & 3.4 \\
\hline Actual Denial Rate & 17.5 & 14.8 & 18.6 & 20.3 & 12.9 & 18.1 & 21.7 & 16.8 & 21.0 & 25.1 \\
\hline Census Tract Effect & -0.1 & -2.9 & -1.4 & 1.9 & -1.2 & 0.9 & 3.5 & 1.6 & 3.1 & 5.9 \\
\hline Residual $^{7}$ & -0.1 & -0.1 & -0.1 & 0.1 & -0.0 & -0.4 & 0.3 & -0.0 & -0.3 & 0.0 \\
\hline \multicolumn{11}{|c|}{ HOMELMPROVEMENT } \\
\hline \multicolumn{11}{|l|}{ Black Applicants } \\
\hline Percent of Blacks & $100.0 \%$ & $0.9 \%$ & $2.4 \%$ & $5.0 \%$ & $1.5 \%$ & $3.8 \%$ & $14.0 \%$ & $1.8 \%$ & $5.6 \%$ & $65.0 \%$ \\
\hline Actual Denial Rate & 45.1 & 31.5 & 34.5 & 38.6 & 31.4 & 35.3 & 42.4 & 35.3 & 39.2 & 48.4 \\
\hline Census Tract Effect & 7.5 & -3.2 & 1.1 & 4.4 & -1.2 & 1.0 & 5.8 & 0.3 & 5.2 & 9.6 \\
\hline Residual $^{7}$ & 7.6 & 12.1 & 9.4 & 6.8 & 11.4 & 10.5 & 6.9 & 10.7 & 9.0 & 7.2 \\
\hline \multicolumn{11}{|l|}{ Hispanic Applicants } \\
\hline Percent of Hispanics & 100.0 & 1.6 & 8.7 & 15.5 & 1.8 & 7.3 & 20.9 & 1.7 & 5.1 & 37.3 \\
\hline Actual Denial Rate & 38.6 & 27.8 & 31.6 & 35.8 & 30.5 & 34.7 & 39.5 & 29.3 & 38.2 & 43.0 \\
\hline Census Tract Effect & 2.5 & -4.3 & -1.9 & 3.4 & -1.6 & -0.4 & 2.7 & 0.5 & 3.4 & 4.0 \\
\hline Residual $^{7}$ & 6.5 & 7.7 & 7.5 & 5.9 & 6.7 & .7 .1 & 7.4 & 4.1 & 6.5 & 5.9 \\
\hline \multicolumn{11}{|l|}{ While Applicants } \\
\hline Percent of Whites & 100.0 & 11.3 & 12.7 & 4.4 & 19.4 & 10.5 & 4.5 & 19.1 & 10.1 & 8.0 \\
\hline Actual Denial Rate & 22.7 & 15.6 & 21.2 & 27.3 & 15.8 & 23.2 & 32.0 & 21.3 & 28.4 & 39.9 \\
\hline Census Tract Effect & 0.5 & -3.5 & -1.9 & 2.5 & -1.9 & 1.0 & 4.3 & 0.5 & 4.2 & 8.3 \\
\hline Residual $^{7}$ & 0.0 & -0.1 & -0.0 & 0.6 & -0.1 & -0.3 & 0.2 & -0.0 & -0.2 & 0.9 \\
\hline
\end{tabular}

1234567 See notes for table 6 . 
Table 10: Difference in Average Percentage Denial Rates Atributable to Various Sources, Non-Center City, by Neighborhood and Race, $1990 \mathrm{HMDA}$

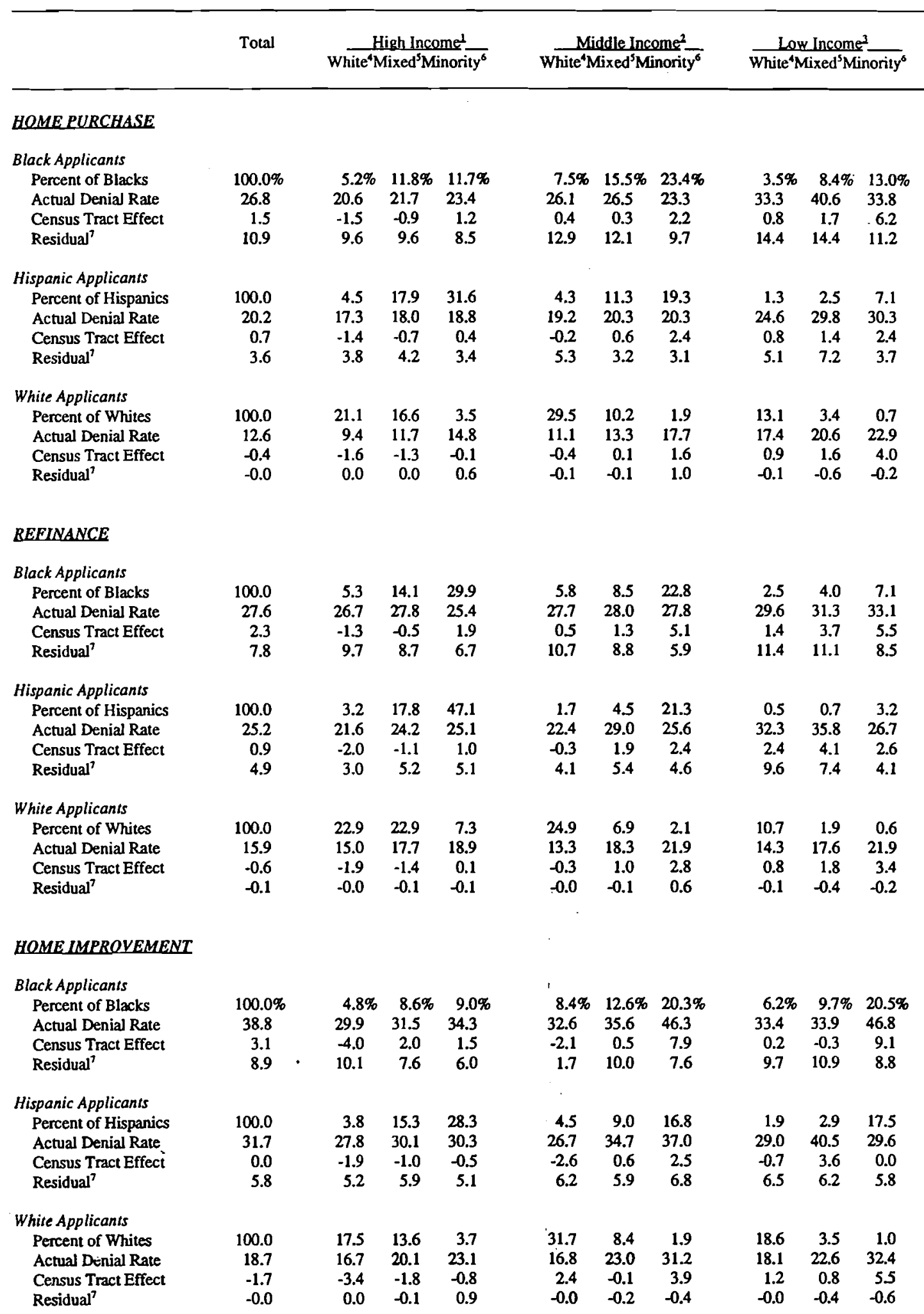

1234367 See notes for table 6. 
Table 11: Difference in Average Percentage Denial Rates Auributabie to Various Sources, Commercial Banks,

by Neighborhood and Race, 1990 HMDA

\begin{tabular}{|c|c|c|c|c|c|c|c|c|c|c|}
\hline HOME PURCHASE & Total & \multicolumn{3}{|c|}{$\frac{\text { High Incomel }}{\text { White'Mixed }^{5} \text { Minority }}$} & \multicolumn{3}{|c|}{$\frac{\text { Middle Income }}{\text { White }^{2} \text { Mix: }}$} & \multicolumn{3}{|c|}{$\frac{\text { Low Income }}{\text { White }^{4} \text { Mixed }^{5} \text { Minority }}$} \\
\hline \multicolumn{11}{|l|}{ Black Applicants } \\
\hline Percent of Blacks & $100.0 \%$ & $3.2 \%$ & $6.1 \%$ & $6.6 \%$ & $5.2 \%$ & $10.9 \%$ & $21.8 \%$ & $3.1 \%$ & $9.2 \%$ & 33.9 \\
\hline Actual Denial Rate & 31.8 & 23.6 & 26.3 & 33.3 & 28.0 & 28.7 & 29.1 & 35.0 & 35.3 & 35.5 \\
\hline Census Tract Effect & 2.6 & -1.7 & -0.5 & 3.1 & -0.6 & 0.6 & 2.6 & 0.8 & 2.1 & 4.7 \\
\hline Residual $^{7}$ & 11.4 & 10.9 & 10.9 & 10.9 & 126 & 12.4 & 10.0 & 14.6 & 12.5 & 11.5 \\
\hline \multicolumn{11}{|l|}{ Hispanic Applicants } \\
\hline Percent of Hispanics & 100.0 & 3.6 & 11.8 & 17.7 & 4.3 & 10.7 & 19.8 & 2.1 & 5.3 & 24.5 \\
\hline Actual Denial Rate & 28.8 & 19.1 & 25.7 & 29.1 & 22.3 & 25.9 & 29.9 & 30.2 & 31.0 & 32.6 \\
\hline Census Tract Effect & 1.5 & -1.3 & -0.5 & 1.5 & -0.2 & 0.4 & 2.7 & 1.2 & 2.0 & 2.7 \\
\hline Residual ${ }^{7}$ & 5.7 & 5.0 & 6.3 & 6.6 & 6.5 & 5.8 & 5.6 & 8.5 & 6.7 & 4.3 \\
\hline \multicolumn{11}{|l|}{ White Applicants } \\
\hline Percent of Whites & 100.0 & 18.8 & 12.1 & 2.4 & 28.4 & 10.3 & 2.2 & 17.3 & 6.0 & 2.4 \\
\hline Actual Denial Rate & 15.5 & 10.4 & 14.2 & 20.7 & 13.3 & 16.1 & 22.0 & 20.0 & 22.3 & 25.8 \\
\hline Census Tract Effect & -0.2 & -1.8 & -1.2 & 0.9 & -0.6 & 0.1 & 2.2 & 0.9 & 1.8 & 3.7 \\
\hline Residual $^{7}$ & -0.2 & -0.4 & -0.6 & -0.0 & -0.1 & -0.1 & 0.9 & 0.0 & -0.1 & 0.3 \\
\hline \multicolumn{11}{|l|}{ REEINANCE } \\
\hline \multicolumn{11}{|l|}{ Black Applicants } \\
\hline Percent of Blacks & 100.0 & 3.8 & 9.7 & 17.4 & 5.4 & 8.4 & 21.5 & 2.9 & 6.5 & 24.3 \\
\hline Actual Denial Rate & 35.1 & 28.7 & 32.1 & 38.1 & 28.5 & 33.2 & 36.6 & 25.9 & 31.2 & 37.8 \\
\hline Census Tract Effect & 3.5 & -1.2 & -0.5 & 2.7 & 0.3 & 1.4 & 4.5 & 1.0 & 3.1 & 7.4 \\
\hline Residual? & 9.7 & 10.6 & 9.8 & 10.1 & 11.5 & 11.8 & 8.1 & 10.0 & 10.0 & 9.6 \\
\hline \multicolumn{11}{|l|}{ Hispanic Applicants } \\
\hline Percent of Hispanics & 100.0 & 3.2 & 17.2 & 36.2 & 2.2 & 5.3 & 20.3 & 1.1 & 1.9 & 12.6 \\
\hline Actual Denial Rate & 32.1 & 28.6 & 29.1 & 33.4 & 28.3 & 35.0 & 33.0 & 29.7 & 39.8 & 30.1 \\
\hline Census Tract Effect & 1.5 & -2.0 & -1.6 & 1.6 & 0.0 & 2.0 & 2.2 & 1.2 & 5.0 & 4.5 \\
\hline Residual $^{7}$ & 6.7 & 7.7 & 5.3 & 6.9 & 9.5 & 7.9 & 6.8 & 7.8 & 9.9 & 5.9 \\
\hline \multicolumn{11}{|l|}{ White Applicants } \\
\hline Percent of Whites & 100.0 & 20.7 & 17.4 & 5.1 & 26.6 & 7.3 & 2.3 & 15.2 & 3.6 & 1.7 \\
\hline Actual Denial Rate & 16.8 & 15.3 & 20.9 & 24.4 & 13.4 & 19.3 & 25.2 & 14.1 & 18.8 & 21.6 \\
\hline Census Tract Effect & -0.5 & -2.4 & -1.6 & 0.4 & -0.4 & 0.8 & 2.7 & 0.7 & 2.2 & 5.1 \\
\hline Residual $^{7}$ & -0.3 & -0.3 & -0.9 & -0.4 & -0.0 & -0.3 & 0.8 & 0.0 & -0.2 & -0.5 \\
\hline
\end{tabular}

\section{HOME IMPROVEMENT}

Black Applicants

Percent of Blacks

Actual Denial Rate

Census Tract Effect

Residual ${ }^{7}$

Hispanic Applicants

Percent of Hispanics

Actual Denial Rate

Census Tract Effect

Residual ${ }^{7}$

White Applicants

Percent of Whites

Actual Denial Rate

Census Tract Effect

Residual $^{7}$

$\begin{array}{cccc}100.0 \% & 1.9 \% & 3.9 \% & 5.4 \% \\ 44.6 & 31.7 & 34.9 & 39.8 \\ 6.5 & -3.6 & -1.7 & 3.2 \\ 8.5 & 10.7 & 9.3 & 7.7 \\ & & & \\ & & & \\ 100.0 & 2.5 & 11.4 & 20.3 \\ 36.3 & 29.9 & 31.2 & 33.4 \\ 1.4 & -2.7 & -1.4 & 1.1 \\ 6.3 & 6.3 & 6.3 & 5.5 \\ & & & \\ 100.0 & 14.6 & 13.2 & 3.8 \\ 21.0 & 16.9 & 21.0 & 25.8 \\ -0.9 & -3.7 & -1.9 & 0.4 \\ -0.1 & -0.4 & -0.3 & 0.6\end{array}$

$\begin{array}{rrr}3.1 \% & 6.9 \% & 55.2 \% \\ 35.4 & 37.9 & 49.1 \\ 0.2 & 2.8 & 9.7 \\ 10.5 & 10.4 & 7.8 \\ & & \\ 1.8 & 4.1 & 31.4 \\ 31.2 & 42.0 & 38.7 \\ 0.1 & 3.8 & 2.3 \\ 5.5 & 6.3 & 5.8 \\ & & \\ & & \\ 20.5 & 6.2 & 3.6 \\ 19.8 & 27.4 & 38.4 \\ -0.6 & 2.9 & 7.7 \\ -0.0 & -0.1 & 0.6\end{array}$

1234367 See notes for table 6 . 
Table 12: Difference in Average Percentage Denial Rates Attributable to Various Sources, Thrift Institutions, by Neighborhood and Race, 1990 HMDA

\begin{tabular}{|c|c|c|c|c|c|c|c|c|c|c|}
\hline \multirow[b]{2}{*}{ HOME PURCHASE } & \multirow[t]{2}{*}{ Total } & \multicolumn{3}{|c|}{$\frac{\text { High Income }}{\text { White }^{4} \text { Mixed }^{5} \text { Minority }}$} & \multicolumn{3}{|c|}{$\frac{\text { Middle Income }}{\text { White }^{4} \text { Mixed }^{5} \text { Minority }^{6}}$} & \multicolumn{3}{|c|}{$\frac{\text { Low Income }}{\text { White }^{4} \text { Mixed }^{5} \text { Minority }^{6}}$} \\
\hline & & & & & & & & & & \\
\hline \multicolumn{11}{|l|}{ Black Applicants } \\
\hline Percent of Blacks & $100.0 \%$ & $4.0 \%$ & $9.9 \%$ & $14.5 \%$ & $5.1 \%$ & $11.9 \%$ & $21.8 \%$ & $2.3 \%$ & $8.2 \%$ & $22.2 \%$ \\
\hline Actual Denial Rate & 28.4 & 23.0 & 23.9 & 22.0 & 27.6 & 28.4 & 25.1 & 31.3 & 41.5 & 33.8 \\
\hline Census Tract Effect & 2.2 & -1.7 & -0.7 & 1.7 & -0.7 & 0.7 & 2.9 & 0.8 & 2.2 & 5.2 \\
\hline Residual? & 10.9 & 12.0 & 11.1 & 7.8 & 15.3 & 13.3 & 9.4 & 15.4 & 14.5 & 9.8 \\
\hline \multicolumn{11}{|l|}{ Hispanic Applicants } \\
\hline Percent of Hispanics & 100.0 & 3.4 & 15.2 & 33.3 & 2.8 & 8.4 & 22.4 & 0.8 & 2.6 & 11.0 \\
\hline Acrual Denial Rate & 20.0 & 17.5 & 17.2 & 17.9 & 19.7 & 19.3 & 20.1 & 22.8 & 28.1 & 29.1 \\
\hline Census Tract Effect & 1.5 & -1.6 & -0.6 & 1.5 & -0.5 & 0.7 & 0.3 & 0.5 & 1.2 & 3.7 \\
\hline Residual ${ }^{7}$ & 3.1 & 3.5 & 3.5 & 2.8 & 5.3 & 2.4 & 3.0 & 5.6 & 5.7 & 2.9 \\
\hline \multicolumn{11}{|l|}{ White Applicants } \\
\hline Percent of Whites & 100.0 & 19.3 & 20.3 & 5.4 & 25.0 & 10.8 & 3.0 & 10.2 & 4.3 & 1.7 \\
\hline Actual Denial Rate & 11.5 & 8.8 & 11.0 & 13.5 & 9.4 & 12.1 & 16.1 & 14.1 & 19.4 & 24.3 \\
\hline Census Tract Effect & -0.4 & -1.7 & -1.1 & 0.6 & -0.6 & 0.2 & 2.4 & 0.6 & 1.7 & 4.2 \\
\hline Residual ${ }^{7}$ & 0.1 & 0.2 & 0.3 & 0.8 & -0.1 & -0.4 & 0.7 & -0.1 & -0.8 & 1.4 \\
\hline \multicolumn{11}{|l|}{ REEINANCE } \\
\hline \multicolumn{11}{|l|}{ Black Applicants } \\
\hline Percent of Blacks & 100.0 & 2.7 & 9.9 & 33.9 & 2.2 & 4.4 & 30.7 & 1.0 & 2.0 & 13.2 \\
\hline Actual Denial Rate & 25.3 & 26.1 & 27.3 & 21.3 & 26.5 & 31.4 & 23.5 & 39.0 & 37.7 & 32.6 \\
\hline Census Tract Effect & 3.4 & -1.7 & -0.8 & 2.7 & 0.3 & 2.4 & 4.7 & 2.2 & 5.3 & 6.7 \\
\hline Residual $^{7}$ & 6.4 & 9.8 & 10.3 & 5.1 & 9.4 & 10.9 & 5.1 & 16.6 & 12.0 & 5.6 \\
\hline \multicolumn{11}{|l|}{ Hispanic Applicants } \\
\hline Percent of Hispanics & 100.0 & 2.5 & 16.1 & 48.0 & 1.1 & 3.8 & 24.0 & 0.3 & 0.6 & 3.6 \\
\hline Actual Denial Rate & 23.3 & 20.9 & 21.8 & 22.6 & 25.0 & 29.4 & 23.8 & 37.0 & 32.2 & 27.7 \\
\hline Census Tract Effect & 1.8 & -2.1 & -0.9 & 2.2 & 0.2 & 1.8 & 2.9 & 3.6 & 1.6 & 4.4 \\
\hline Residual ${ }^{7}$ & 4.3 & 2.1 & 4.4 & 4.2 & 2.5 & 5.7 & 4.5 & 9.6 & 4.4 & 3.6 \\
\hline \multicolumn{11}{|l|}{ White Applicants } \\
\hline Percent of Whites & 100.0 & 20.6 & 28.1 & 10.4 & 18.9 & 7.8 & 3.8 & 6.7 & 2.3 & 1.4 \\
\hline Actual Denial Rate & 16.2 & 14.4 & 16.9 & 17.7 & 12.9 & 18.2 & 20.6 & 16.6 & 22.0 & 27.7 \\
\hline Census Tract Effect & -0.3 & -2.0 & -1.3 & 1.0 & -0.5 & 1.2 & 3.5 & 1.7 & 3.1 & 5.5 \\
\hline Residual? & 0.1 & 0.0 & 0.3 & 0.2 & -0.1 & -0.1 & 0.5 & -0.2 & -0.3 & 0.4 \\
\hline
\end{tabular}

\section{HOME IMPROVEMENT}

$\begin{array}{lcccccccccc}\text { Black Applicants } & & & & & & & & & \\ \text { Percent of Blacks } & 100.0 \% & 2.3 \% & 4.6 \% & 8.7 \% & 3.5 \% & 6.0 \% & 21.1 \% & 2.4 \% & 5.0 \% & 46.5 \% \\ \text { Actual Denial Rate } & 49.5 & 35.1 & 35.7 & 37.6 & 36.8 & 44.2 & 50.7 & 38.7 & 46.5 & 55.8 \\ \text { Census Tract Effect } & 6.3 & -4.2 & 1.7 & 3.5 & -1.6 & 0.8 & 7.5 & 0.9 & 5.0 & 9.4 \\ \text { Residual' } & 7.5 & 12.6 & 7.6 & 5.2 & 13.0 & 13.8 & 5.7 & 10.9 & 9.4 & 6.9 \\ & & & & & & & & & & \\ \text { Hispanic Applicants } & & & & & & & & & & \\ \text { Percent of Hispanics } & 100.0 & 2.9 & 13.3 & 27.8 & 3.1 & 7.6 & 25.0 & 1.2 & 2.6 & 16.6 \\ \text { Actual Denial Rate } & 38.1 & 25.3 & 33.4 & 31.1 & 34.6 & 39.4 & 38.3 & 33.0 & 46.7 & 54.3 \\ \text { Census Tract Effect } & 1.6 & -3.6 & -1.1 & 1.0 & -2.6 & -0.6 & 2.0 & -1.0 & 4.4 & 6.8 \\ \text { Residual } & 6.9 & 4.0 & 8.8 & 5.3 & 1.2 & 7.5 & 5.7 & 8.8 & 10.2 & 8.4 \\ & & & & & & & & & & \\ \text { White Applicants }^{\text {Percent of Whites }} & 100.0 & 17.6 & 14.2 & 4.6 & 28.4 & 9.6 & 3.9 & 14.0 & 4.1 & 3.6 \\ \text { Actual Denial Rate } & 22.1 & 17.7 & 22.2 & 24.5 & 17.4 & 25.7 & 34.5 & 21.5 & 30.6 & 47.2 \\ \text { Census Tract Effect } & -0.9 & -3.2 & -1.6 & 0.9 & -2.2 & -0.2 & 4.9 & -0.5 & 3.2 & 8.2 \\ \text { Residual } & -0.0 & 0.3 & 0.3 & 1.0 & -0.5 & -0.5 & -0.7 & -0.2 & -0.4 & 2.0\end{array}$

1234567 See notes for table 6. 
Table 13: Difference in Average Percentage Denial Rates Attributable to Various Sources, Mortgage Banks, by Neighborhood and Race, 1990 HMDA

\begin{tabular}{|c|c|c|c|c|c|c|c|c|c|c|}
\hline \multirow[b]{2}{*}{ HOME PURCHASE } & \multirow[t]{2}{*}{ Total } & \multicolumn{3}{|c|}{$\frac{\text { High Income }}{\text { White }^{4} \text { Mixed }^{3} \text { Minority }^{6}}$} & \multicolumn{3}{|c|}{$\frac{\text { Middle Income }{ }^{2}}{\text { White'Mixed }^{3} \text { Minority }}$} & \multicolumn{3}{|c|}{$\frac{\text { Low Income }}{\text { White }^{4} \text { Mixed }}$} \\
\hline & & & & & & & & & & \\
\hline \multicolumn{11}{|l|}{ Black Applicants } \\
\hline Percent of Blacks & $100.0 \%$ & $2.9 \%$ & $7.4 \%$ & $7.4 \%$ & $4.4 \%$ & $12.1 \%$ & $22.2 \%$ & $2.3 \%$ & $6.9 \%$ & $34.4 \%$ \\
\hline Actual Denial Rate & 25.6 & 18.9 & 20.4 & 24.9 & 20.2 & 22.4 & 24.3 & 25.1 & 30.7 & 29.0 \\
\hline Census Tract Effect & 2.6 & -1.5 & -0.6 & 1.9 & -0.8 & 0.6 & 2.7 & 0.5 & 1.9 & 5.1 \\
\hline Residual ${ }^{7}$ & 10.5 & 8.5 & 9.4 & 9.7 & 11.3 & 9.9 & 10.5 & 12.2 & 14.5 & 10.2 \\
\hline \multicolumn{11}{|l|}{ Hispanic Applicants } \\
\hline Percent of Hispanics & 100.0 & 2.8 & 13.5 & 20.8 & 3.2 & 14.4 & 24.9 & 1.0 & 4.0 & 15.3 \\
\hline Actual Denial Rate & 16.4 & 12.6 & 15.7 & 17.2 & 12.9 & 15.1 & 16.4 & 10.1 & 19.6 & 18.2 \\
\hline Census Tract Effect & 1.1 & -1.8 & -0.7 & 1.1 & -0.6 & 0.6 & 2.4 & -0.0 & 0.8 & 2.4 \\
\hline Residual ${ }^{7}$ & 2.0 & 2.2 & 3.0 & 2.1 & 4.2 & 2.3 & 1.3 & -1.4 & 3.5 & 1.0 \\
\hline \multicolumn{11}{|l|}{ White Applicants } \\
\hline Percent of Whites & 100.0 & 18.0 & 17.8 & 4.4 & 23.5 & 14.0 & 3.6 & 11.1 & 5.3 & 2.4 \\
\hline Actual Denial Rate & 10.6 & 9.0 & 11.8 & 14.5 & 7.9 & 10.7 & 15.1 & 10.6 & 13.5 & 17.1 \\
\hline Census Tract Effect & -0.4 & -1.6 & -1.2 & 0.4 & -0.7 & 0.1 & 2.0 & 0.4 & 1.3 & 3.6 \\
\hline Residual ${ }^{7}$ & 0.1 & 0.5 & 0.0 & 0.2 & 0.1 & 0.4 & 0.7 & -0.5 & -0.5 & -0.3 \\
\hline \multicolumn{11}{|l|}{ REEINANCE } \\
\hline \multicolumn{11}{|l|}{ Black Applicants } \\
\hline Percent of Blacks & 100.0 & 2.8 & 12.2 & 25.6 & 2.7 & 5.0 & 23.5 & 1.3 & 3.2 & 23.7 \\
\hline Actual Denial Rate & 30.2 & 28.2 & 26.5 & 31.4 & 25.0 & 23.7 & 29.8 & 40.0 & 36.4 & 31.9 \\
\hline Census Tract Effect & 3.4 & -1.4 & -0.3 & 2.1 & 0.3 & 0.9 & 5.0 & 6.0 & 4.2 & 6.5 \\
\hline Residual $^{7}$ & 7.2 & 7.9 & 5.9 & 8.1 & 8.0 & 3.8 & 5.9 & 9.2 & 17.2 & 7.2 \\
\hline \multicolumn{11}{|l|}{ Hispanic Applicants } \\
\hline Percent of Hispanics & 100.0 & 2.6 & 21.0 & 44.6 & 1.3 & 4.5 & 20.7 & 0.3 & 0.9 & 4.0 \\
\hline Actual Denial Rate & 25.7 & 21.4 & 23.6 & 27.1 & 19.4 & 17.1 & 28.4 & 13.3 & 22.7 & 23.6 \\
\hline Census Tract Effect & 1.0 & -2.7 & -1.2 & 1.3 & -1.3 & 0.8 & 2.2 & -0.5 & 2.7 & 5.0 \\
\hline Residual $^{7}$ & 4.0 & 4.3 & 5.2 & 4.2 & 4.3 & 1.1 & 3.8 & -2.8 & 3.5 & -0.1 \\
\hline \multicolumn{11}{|l|}{ White Applicants } \\
\hline Percent of Whites & 100.0 & 21.6 & 33.4 & 12.1 & 14.1 & 7.4 & 3.6 & 4.4 & 2.2 & 1.3 \\
\hline Actual Denial Rate & 18.1 & 18.6 & 17.6 & 19.7 & 17.0 & 17.0 & 19.7 & 18.8 & 16.7 & 23.5 \\
\hline Census Tract Effect & -0.6 & -2.0 & -1.5 & 0.7 & -0.4 & 1.2 & 2.6 & 0.5 & 2.8 & 5.4 \\
\hline Residual $^{7}$ & 0.1 & 0.9 & -0.2 & -0.2 & 0.7 & -0.2 & -0.9 & 0.3 & -2.1 & -0.3 \\
\hline \multicolumn{11}{|l|}{ HOME IMPROVEMENT } \\
\hline \multicolumn{11}{|l|}{ Black Applicants } \\
\hline Percent of Blacks & $100.0 \%$ & $2.4 \%$ & $9.4 \%$ & $15.7 \%$ & $2.0 \%$ & $4.9 \%$ & $24.4 \%$ & $1.4 \%$ & $3.3 \%$ & $36.4 \%$ \\
\hline Actual Denial Rate & 29.9 & 41.7 & 27.1 & 31.3 & 10.0 & 24.0 & 21.0 & 14.3 & 41.2 & 36.8 \\
\hline Census Tract Effect & 4.7 & -2.7 & -1.0 & -0.5 & -5.4 & -0.2 & 6.8 & 1.1 & 2,4 & 9.1 \\
\hline Residual $^{7}$ & 3.0 & 13.5 & 3.6 & -2.4 & -1.4 & 4.3 & -1.8 & -1.5 & 14.4 & 7.0 \\
\hline \multicolumn{11}{|l|}{ Hispanic Applicants } \\
\hline Percent of Hispanics & 100.0 & 3.4 & 16.4 & 38.4 & 1.6 & 7.4 & 21.0 & 0.4 & 1.8 & 9.6 \\
\hline Actual Denial Rate & 34.4 & 29.4 & 30.5 & 43.8 & 0.0 & 16.2 & 39.0 & 0.0 & 22.2 & 18.8 \\
\hline Census Tract Effect & 0.6 & 3.8 & -3.0 & 1.1 & -0.5 & -1.7 & -0.4 & 6.7 & 3.5 & 6.5 \\
\hline Residual $^{7}$ & 2.7 & $10.1^{\circ}$ & -4.3 & 5.5 & 1.4 & -5.4 & 7.3 & -1.8 & -6.7 & 0.2 \\
\hline \multicolumn{11}{|l|}{ White Applicants } \\
\hline Percent of Whites & 100.0 & 17.4 & 26.2 & 11.3 & 15.8 & 10.7 & 5.1 & 6.1 & 4.5 & 2.9 \\
\hline Actual Denial Rate & 24.6 & 25.1 & 28.2 & 35.6 & 19.2 & 20.0 & 25.3 & 18.3 & 14.7 & 20.6 \\
\hline Census Tract Effect & -0.5 & -3.2 & -0.9 & 1.0 & -2.4 & 0.6 & 4.1 & -0.9 & 3.0 & 5.8 \\
\hline Residual ${ }^{7}$ & 0.6 & 1.0 & 0.9 & 2.2 & 0.3 & 0.8 & -1.1 & -0.9 & -0.8 & -1.7 \\
\hline
\end{tabular}


Table 14: Difference in Average Percentage Denial Rates, Neighborhoods Sorted by Percentage Black, 1990 HMDA

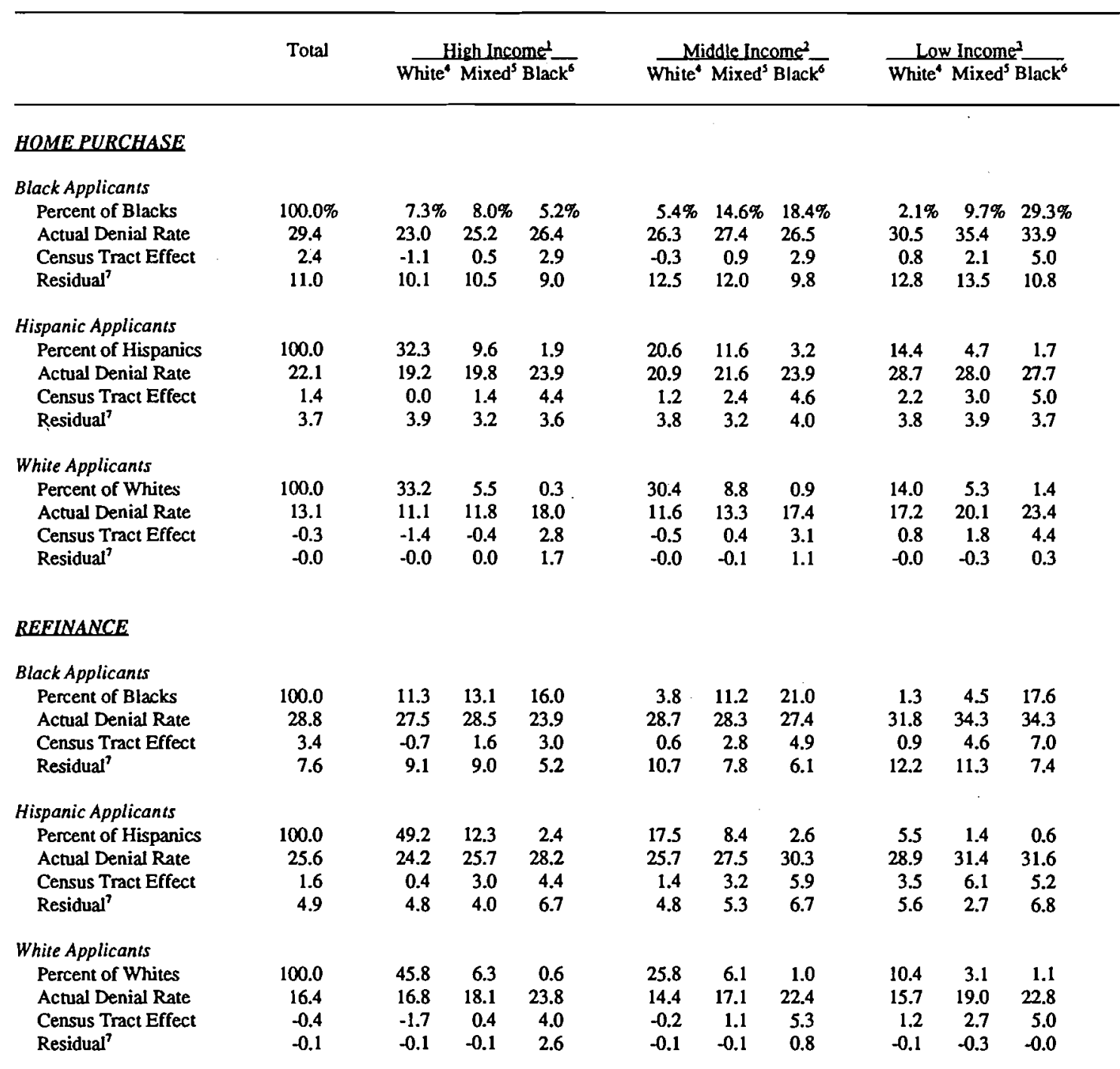


Table 14: (continued)

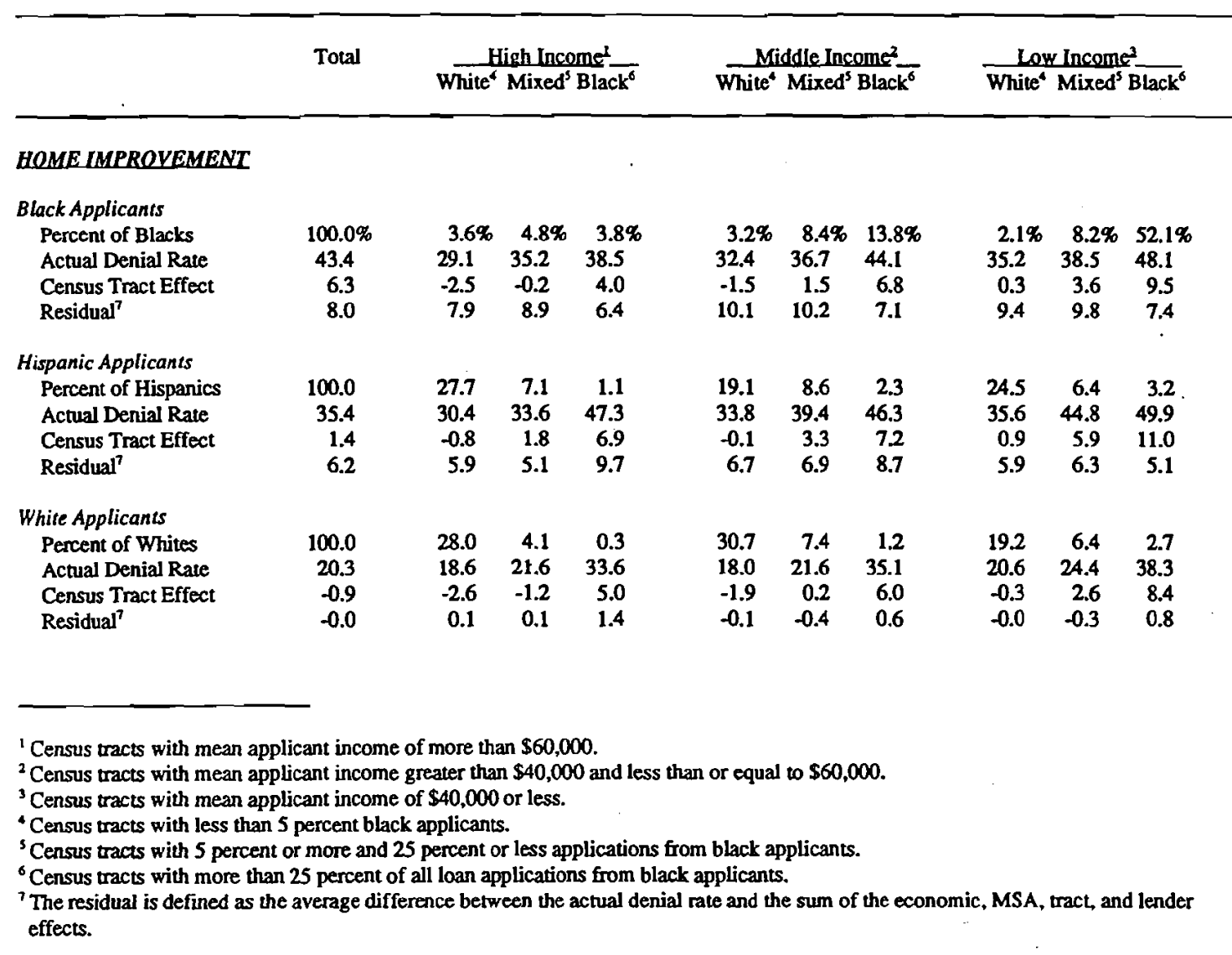


Table 15: Difference in Average Percentage Denial Rates, Neighborhoods Sorted by Percentage Hispanic, 1990 HMDA

\begin{tabular}{|c|c|c|c|c|c|c|c|c|c|c|}
\hline \multirow[b]{2}{*}{ HOME PURCHASE } & \multirow[t]{2}{*}{ Total } & \multicolumn{3}{|c|}{$\frac{\text { High Incomed }}{\text { White'Mixed }^{4} \text { Hispanic }^{6}}$} & \multicolumn{3}{|c|}{$\frac{\text { Middle Income }}{\text { White }^{4} \text { Mixed }^{3} \text { Hispanic }^{6}}$} & \multicolumn{3}{|c|}{$\frac{\text { Low Income }}{\text { White }^{4} \text { Mixed }^{5} \text { Hispanic }^{6}}$} \\
\hline & & & & & & & & & & \\
\hline \multicolumn{11}{|l|}{ Black Applicants } \\
\hline Percent of Blacks & $100.0 \%$ & $10.9 \%$ & $8.1 \%$ & $1.6 \%$ & $25.4 \%$ & $10.8 \%$ & $2.1 \%$ & $34.3 \%$ & $5.5 \%$ & $1.2 \%$ \\
\hline Actual Denial Rate & 29.4 & 23.3 & 26.1 & 27.5 & 25.9 & 28.2 & 30.7 & 34.5 & 31.3 & 35.7 \\
\hline Census Tract Effect & 2.4 & -0.4 & 1.4 & 2.3 & 1.1 & 2.6 & 4.4 & 4.2 & 3.3 & 4.4 \\
\hline Residual $^{7}$ & 11.0 & 10.4 & 9.5 & 9.6 & 11.7 & 9.6 & 10.5 & 11.8 & 10.1 & 11.6 \\
\hline \multicolumn{11}{|l|}{ Hispanic Applicants } \\
\hline Percent of Hispanics & 100.0 & 5.5 & 20.1 & 18.2 & 4.4 & 14.4 & 16.6 & 1.9 & 4.8 & 14.0 \\
\hline Actual Denial Rate & 22.1 & 16.7 & 20.0 & 19.8 & 17.8 & 21.8 & 22.0 & 24.5 & 27.8 & 29.3 \\
\hline Census Tract Effect & 1.4 & -1.4 & 0.2 & 1.5 & -0.1 & 1.3 & 2.9 & 1.4 & 2.3 & 2.9 \\
\hline Residual $^{7}$ & 3.7 & 4.6 & 4.0 & 3.1 & 4.3 & 3.9 & 3.2 & 5.1 & 5.1 & 3.2 \\
\hline \multicolumn{11}{|l|}{ White Applicants } \\
\hline Percent of Whites & 100.0 & 26.7 & 11.3 & 1.1 & 32.1 & 7.2 & 0.8 & 17.8 & 2.4 & 0.6 \\
\hline Actual Denial Rate & 13.1 & 9.9 & 13.9 & 17.4 & 11.2 & 15.4 & 20.2 & 17.9 & 20.5 & 24.5 \\
\hline Census Tract Effect & -0.3 & -1.6 & -0.5 & 0.6 & -0.5 & 0.5 & 2.5 & 1.2 & 2.0 & 2.7 \\
\hline Residual ${ }^{7}$ & -0.0 & -0.0 & -0.0 & 1.2 & -0.1 & 0.1 & 1.0 & -0.1 & -0.0 & 0.3 \\
\hline \multicolumn{11}{|l|}{ REEINANCE } \\
\hline \multicolumn{11}{|l|}{ Black Applicants } \\
\hline Percent of Blacks & 100.0 & 13.8 & 19.2 & 7.4 & 16.3 & 12.0 & 7.8 & 19.5 & 3.3 & 0.7 \\
\hline Actual Denial Rate & 28.8 & 26.0 & 27.1 & 25.4 & 28.6 & 29.2 & 23.9 & 34.1 & 34.0 & 38.0 \\
\hline Census Tract Effect & 3.4 & 0.1 & 1.6 & 4.2 & 2.6 & 4.6 & 4.8 & 6.0 & 6.9 & 6.9 \\
\hline Residual $^{7}$ & 7.6 & 8.4 & 7.6 & 5.7 & 8.9 & 6.8 & 3.9 & 8.7 & 6.4 & 11.4 \\
\hline \multicolumn{11}{|l|}{$H$ 'spanic Applicants } \\
\hline Percent of Hispanics & 100.0 & 5.5 & 27.8 & 30.6 & 1.9 & 7.2 & 19.4 & 0.7 & 1.6 & 5.3 \\
\hline Actual Denial Rate & 25.6 & 21.2 & 24.5 & 25.4 & 24.9 & 29.5 & 25.7 & 31.0 & 32.9 & 28.4 \\
\hline Census Tract Effect & 1.6 & -2.1 & 0.1 & 2.4 & 0.1 & 2.6 & 2.5 & 2.5 & 3.1 & 4.7 \\
\hline Residual $^{7}$ & 4.9 & 3.9 & 5.0 & 4.6 & 5.5 & $5.6^{\circ}$ & 4.9 & 6.7 & 7.0 & 4.4 \\
\hline \multicolumn{11}{|l|}{ White Applicants } \\
\hline Percent of Whites & 100.0 & 31.3 & 19.0 & 2.3 & 25.8 & 5.7 & 1.2 & 12.8 & 1.4 & 0.4 \\
\hline Actual Denial Rate & 16.4 & 15.6 & 19.1 & 21.0 & 13.4 & 21.6 & 22.5 & 15.9 & 23.5 & 26.3 \\
\hline Census Tract Effect & -0.4 & -2.2 & -0.4 & 1.7 & -0.3 & 2.0 & 0.9 & 1.5 & 3.3 & 5.7 \\
\hline Residual ${ }^{7}$ & -0.1 & -0.0 & -0.1 & 0.2 & -0.1 & -0.1 & 0.8 & -0.1 & -0.2 & -0.1 \\
\hline
\end{tabular}


Table 15: (continued)

\begin{tabular}{|c|c|c|c|c|c|c|c|c|c|c|}
\hline HOME IMPROVEMEN & Total & \multicolumn{3}{|c|}{$\frac{\text { High Incomed }}{\text { White }}$} & \multicolumn{3}{|c|}{$\frac{\text { Middle Income }}{\text { White }^{4} \text { Mixed }^{3} \text { Minority }^{6}}$} & \multicolumn{3}{|c|}{$\frac{\text { Low Income }}{\text { White }^{4} \text { Mixed }^{5} \text { Minority }^{6}}$} \\
\hline \multicolumn{11}{|l|}{ Black Applicants } \\
\hline Percent of Blacks & $100.0 \%$ & $6.7 \%$ & $4.3 \%$ & $1.2 \%$ & $17.6 \%$ & $6.0 \%$ & $1.7 \%$ & $54.8 \%$ & $6.4 \%$ & $1.3 \%$ \\
\hline Actual Denial Rate & 43.4 & 33.4 & 35.2 & 37.8 & 39.3 & 43.0 & 39.5 & 46.0 & 48.7 & 51.0 \\
\hline Census Tract Effect & 6.3 & -0.9 & 1.6 & 4.2 & 3.4 & 5.5 & 5.3 & 8.2 & 9.5 & 9.0 \\
\hline Residual' & 8.0 & 8.8 & 6.9 & 5.4 & 9.2 & 7.8 & 3.9 & 7.8 & 7.5 & 7.2 \\
\hline \multicolumn{11}{|l|}{ Hispanic Applicants } \\
\hline Percent of Hispanics & 100.0 & 5.0 & 17.5 & 13.4 & 3.7 & 11.9 & 14.6 & 2.6 & 6.2 & 25.3 \\
\hline Actual Denial Rate & 35.4 & 27.6 & 31.4 & 33.1 & 27.6 & 37.3 & 37.8 & 32.6 & 42.0 & 38.4 \\
\hline Census Tract Effect & 1.4 & -2.1 & -0.3 & 1.0 & -1.3 & 1.7 & 2.0 & 2.5 & 5.8 & 2.1 \\
\hline Residual & 6.2 & 5.5 & 6.3 & 5.3 & 5.1 & 6.9 & 7.3 & 5.2 & 5.8 & 6.0 \\
\hline \multicolumn{11}{|l|}{ White Applicants } \\
\hline Percent of Whites & 100.0 & 21.8 & 5.7 & 1.0 & 32.4 & 5.9 & 0.9 & 24.7 & 2.8 & 0.8 \\
\hline Actual Denial Rate & 20.3 & 17.3 & 22.4 & 25.9 & 17.4 & 27.4 & 29.8 & 21.6 & 32.6 & 36.8 \\
\hline Census Tract Effect & -0.9 & -3.1 & -0.8 & 0.3 & -1.8 & 0.9 & 2.2 & 0.7 & 4.5 & 4.2 \\
\hline Residual $^{7}$ & -0.0 & 0.0 & 0.1 & 0.8 & -0.1 & -0.1 & -0.2 & -0.0 & -0.0 & 0.3 \\
\hline \multicolumn{11}{|c|}{$\begin{array}{l}\text { 'Census tracts with mean applicant income of more than } \$ 60,000 \text {. } \\
2 \text { Census tracts with mean applicant income greater than } \$ 40,000 \text { and less than or equal to } \$ 60,000 \text {. } \\
{ }^{3} \text { Census tracts with mean applicant income of } \$ 40,000 \text { or less. } \\
4 \text { Census tracts with less than } 5 \text { percent Hispanic applicants. } \\
\text { ' Census tracts with } 5 \text { percent or more and } 25 \text { percent or less applications from Hispanic applicants. } \\
{ }^{6} \text { Census tracts with more than } 25 \text { percent of all loan applications from Hispanic applicants. } \\
\text { 'The residual is defined as the average difference between the actual denial rate and the sum of the economic, MSA, tract, and lender } \\
\text { effects. }\end{array}$} \\
\hline
\end{tabular}


Table 16: Neighborhood and Unexplained Denial Rate Residuals, Blacks, by MSA, 1990 HMDA

\begin{tabular}{|c|c|c|c|c|c|c|c|c|c|c|c|c|}
\hline \multirow[b]{3}{*}{ All MSAs $<1$ Million } & \multirow[b]{2}{*}{$\begin{array}{r}\text { Percent } \\
\text { Black }\end{array}$} & \multicolumn{3}{|c|}{ Home Purchase } & \multirow[b]{2}{*}{$\begin{array}{r}\text { Percent } \\
\text { Black }\end{array}$} & \multicolumn{3}{|c|}{ Refinance } & \multicolumn{4}{|c|}{ Home Improvement } \\
\hline & & $\begin{array}{l}\text { Denial } \\
\text { Rate }\end{array}$ & $\begin{array}{l}\text { Tract } R \\
\text { Effect }\end{array}$ & $\begin{array}{l}\text { Residual } \\
\text { Effect }\end{array}$ & & $\begin{array}{l}\text { Denial } \\
\text { Rate }\end{array}$ & $\begin{array}{l}\text { Tract } R \\
\text { Effect }\end{array}$ & $\begin{array}{l}\text { Residual } \\
\text { Effect }\end{array}$ & $\begin{array}{r}\text { Percent } \\
\text { Black }\end{array}$ & $\begin{array}{l}\text { Denial } \\
6 \text { Rate }\end{array}$ & $\begin{array}{l}\text { Tract } R \\
\text { Effect }\end{array}$ & $\begin{array}{l}\text { Residual } \\
\text { Effect }\end{array}$ \\
\hline & $5.0 \%$ & $33.5 \%$ & $2.4 \%$ & $12.6 \%$ & $3.2 \%$ & $32.1 \%$ & $3.6 \%$ & $9.7 \%$ & $7.5 \%$ & $36.1 \%$ & $4.5 \%$ & $8.9 \%$ \\
\hline All MSAs 1 - 2 Million. & 6.9 & 30.2 & 2.5 & 11.1 & 4.0 & 33.2 & 3.4 & 8.6 & 10.4 & 46.1 & 6.4 & 8.7 \\
\hline Anaheim & 1.1 & 25.3 & 0.6 & 10.6 & 1.2 & 26.2 & 0.1 & 8.3 & 0.8 & 27.0 & -0.4 & 4.6 \\
\hline Atlanta & 16.8 & 31.9 & 5.7 & 12.7 & 7.8 & 31.8 & 2.5 & 8.0 & 19.2 & 39.0 & 4.7 & 10.7 \\
\hline Baltimore & 13.9 & 17.8 & -1.0 & 8.6 & 7.1 & 27.0 & 3.0 & 8.6 & 27.7 & 54.8 & 5.4 & 8.3 \\
\hline Boston & 4.8 & 38.9 & 5.1 & 10.5 & 2.9 & 41.2 & 9.8 & 8.4 & 5.8 & 31.4 & 3.3 & 6.2 \\
\hline Chicago & 9.5 & 25.9 & 4.2 & 10.8 & 8.0 & 36.4 & 7.4 & 7.1 & 20.6 & 47.2 & 8.4 & 6.1 \\
\hline Cleveland & 7.5 & 29.5 & 4.9 & 10.7 & 6.8 & 44.7 & 12.6 & 9.5 & 17.6 & 39.7 & 6.4 & 5.6 \\
\hline Dallas & 5.8 & 28.9 & 2.4 & 11.7 & 2.8 & 26.7 & 5.1 & 4.3 & 7.3 & 54.2 & 12.5 & 9.8 \\
\hline Detroit & 8.5 & 22.7 & 1.0 & 9.1 & 4.1 & 32.4 & 8.6 & 7.7 & 30.1 & 46.6 & 10.3 & 7.7 \\
\hline Houston & 6.1 & 36.1 & 2.8 & 13.5 & 3.5 & 27.0 & 2.9 & 6.0 & 11.0 & 63.7 & 10.7 & 11.7 \\
\hline Los Angeles & 4.7 & 25.1 & 1.4 & 8.8 & 9.0 & 23.9 & 2.8 & 5.4 & 7.1 & 33.8 & 3.2 & 4.8 \\
\hline Miami & 7.4 & 26.1 & 3.6 & 6.1 & 5.5 & 43.4 & 2.3 & 11.0 & 10.5 & 45.4 & 4.8 & 3.6 \\
\hline Minneapolis & 1.7 & 25.1 & 3.1 & 12.7 & .8 & 33.3 & 0.3 & 17.4 & 1.8 & 39.4 & 10.3 & 5.0 \\
\hline Nassau/Suffolk NY & 7.1 & 32.1 & .4 .8 & 9.8 & 6.9 & 26.7 & 2.8 & 5.7 & 6.2 & 38.3 & 4.5 & 6.9 \\
\hline New York & 16.4 & 30.7 & 1.5 & 9.1 & 20.9 & 25.4 & 2.6 & 6.7 & 22.8 & 39.9 & 2.6 & 5.3 \\
\hline Oakland & 5.5 & 20.8 & 2.1 & 7.3 & 9.7 & 25.0 & 3.2 & 6.9 & 6.7 & 33.9 & 3.9 & 8.4 \\
\hline Philadelphia & 9.6 & 27.4 & 1.5 & 10.2 & 4.2 & 32.9 & 4.4 & 9.7 & 16.3 & 57.9 & 10.0 & 7.8 \\
\hline Phoenix & 1.8 & 34.9 & 1.4 & 12.1 & 1.1 & 70.3 & 12.3 & 26.4 & 1.5 & 42.4 & -5.7 & -1.9 \\
\hline Pittsburgh & 4.2 & 35.0 & 3.8 & 12.7 & 1.6 & 47.4 & 8.9 & 20.3 & 10.8 & 53.6 & 11.4 & 7.0 \\
\hline Riverside CA & 4.5 & 24.2 & 0.2 & 9.1 & 4.0 & 29.0 & 0.8 & 7.5 & 3.3 & 35.0 & 0.3 & 7.6 \\
\hline St. Louis & 9.2 & 34.0 & 6.5 & 12.4 & 7.3 & 25.0 & 3.9 & 9.1 & 20.2 & 49.7 & 9.8 & 9.4 \\
\hline San Diego & 1.8 & 22.3 & 1.2 & 7.4 & 2.2 & 34.8 & 4.9 & 11.0 & 3.0 & 32.0 & 1.5 & 7.5 \\
\hline San Francisco & 1.7 & 24.2 & 1.5 & 7.9 & 4.0 & 24.8 & 1.8 & 6.2 & 3.5 & 34.6 & 4.2 & 5.9 \\
\hline Seattle & 1.3 & 21.8 & 0.2 & 7.8 & 1.9 & 29.9 & 2.7 & 13.0 & 1.6 & 33.0 & 5.0 & 8.8 \\
\hline Tampa & 3.7 & 35.3 & 4.9 & 11.3 & 3.4 & 42.8 & 4.8 & 10.9 & 8.7 & 34.0 & 1.7 & 6.9 \\
\hline Washington & 15.7 & 17.4 & 0.7 & 9.1 & 10.6 & 23.9 & 2.5 & 6.8 & 24.7 & 48.2 & 5.4 & 7.6 \\
\hline Total & 6.2 & 29.4 & 2.4 & 11.0 & 5.1 & 28.8 & 3.4 & 7.6 & 10.3 & 43.4 & 6.3 & 8.0 \\
\hline
\end{tabular}


Table 17: Neighborhood and Unexplained Denial Rate Residuals, Hispanics, by MSA, 1990 HMDA

\begin{tabular}{|c|c|c|c|c|c|c|c|c|c|c|c|c|}
\hline \multirow{5}{*}{$\begin{array}{l}\text { All MSAs < } 1 \text { Million } \\
\text { All MSAs } 1 \text { - } 2 \text { Million }\end{array}$} & \multirow{2}{*}{\multicolumn{4}{|c|}{$\begin{array}{c}\text { Home Purchase } \\
\text { Percent Denial Tract Residual } \\
\text { Hispanic Rate Effect Effect }\end{array}$}} & \multirow{2}{*}{\multicolumn{2}{|c|}{$\begin{array}{r}\frac{R}{\text { Percent Denial }} \\
\text { Hispanic Rate }\end{array}$}} & \multicolumn{2}{|c|}{ Zefinance } & \multicolumn{4}{|c|}{ Home Improvement } \\
\hline & & & & & & & $\begin{array}{l}\text { Tract } R \\
\text { Effect }\end{array}$ & $\begin{array}{l}\text { Residual } \\
\text { Effect }\end{array}$ & $\begin{array}{l}\text { Percent } \\
\text { Hispan }\end{array}$ & $\begin{array}{l}\text { Denial } \\
\text { ic Rate }\end{array}$ & $\begin{array}{l}\text { Tract } R \\
\text { Effect }\end{array}$ & $\begin{array}{l}\text { Residual } \\
\text { Effect }\end{array}$ \\
\hline & $4.4 \%$ & $25.7 \%$ & $1.2 \%$ & $4.2 \%$ & $3.7 \%$ & $26.9 \%$ & $1.5 \%$ & $5.5 \%$ & $4.6 \%$ & $31.6 \%$ & $1.2 \%$ & $6.7 \%$ \\
\hline & 5.1 & 24.2 & 1.8 & 3.9 & 4.7 & 26.4 & 2.8 & 4.9 & 4.6 & 42.4 & 3.4 & 7.4 \\
\hline & 12.9 & 20.4 & 1.8 & 3.6 & 10.7 & 23.8 & 1.7 & 4.5 & 7.6 & 27.2 & 0.2 & 5.1 \\
\hline Atlanta & 1.0 & 13.7 & 0.3 & -0.1 & 0.4 & 16.0 & 0.7 & -2.7 & 0.7 & 32.7 & 0.5 & 10.0 \\
\hline Baltimore & 0.9 & 12.6 & -0.2 & 4.2 & 0.4 & 21.7 & -1.0 & 10.7 & 0.5 & 46.8 & 3.2 & 9.6 \\
\hline Boston & 2.1 & 22.5 & 2.6 & 4.8 & 1.9 & 25.9 & 3.2 & 7.6 & 2.3 & 38.3 & 6.0 & 8.9 \\
\hline Chicago & 10.7 & 13.0 & 1.4 & 2.5 & 5.4 & 22.6 & 1.9 & 4.2 & 8.6 & 34.9 & -0.5 & 4.7 \\
\hline Cleveland & 0.8 & 20.8 & 3.8 & 3.7 & 0.4 & 30.0 & -1.2 & 14.4 & 1.2 & 38.7 & 5.8 & 7.3 \\
\hline Dallas & 6.1 & 20.9 & 2.4 & 2.4 & 3.3 & 27.3 & 3.9 & 6.9 & 5.5 & 50.9 & 6.2 & 13.6 \\
\hline Detroit & 0.7 & 15.3 & 1.1 & 2.2 & 0.6 & 23.8 & .0 .4 & 7.5 & 1.1 & 30.2 & 0.1 & 2.1 \\
\hline Houston & 8.7 & 29.1 & 2.6 & 6.0 & 3.5 & 18.9 & 2.5 & 4.1 & 9.8 & 54.4 & 6.0 & 10.5 \\
\hline Los Angeles & 25.5 & 20.2 & 1.9 & 3.6 & 23.6 & 24.8 & 1.8 & 4.9 & 18.8 & 31.8 & 0.7 & 5.6 \\
\hline Miami & 44.4 & 20.4 & -0.2 & 3.1 & 44.7 & 32.0 & .0 .5 & 3.8 & 4.8 & 38.7 & -1.3 & 6.3 \\
\hline Minneapolis & 0.5 & 11.2 & 0.9 & 0.8 & 0.3 & 25.0 & 2.5 & 5.8 & 0.3 & 25.0 & 0.7 & 6.3 \\
\hline Nassau/Suffolk NY & 4.8 & 23.9 & 1.9 & 4.5 & 2.8 & 23.4 & 1.4 & 2.2 & 4.0 & 36.8 & 2.5 & 4.9 \\
\hline New York & 8.7 & 27.0 & 2.2 & 5.7 & 8.2 & 25.8 & 2.1 & 4.2 & 10.0 & 45.1 & 3.4 & 7.3 \\
\hline Oakland & 8.1 & 15.7 & 1.7 & 2.5 & 7.8 & 20.4 & 1.2 & 4.2 & 6.6 & 25.1 & 1.1 & 3.7 \\
\hline Philadelphia & 2.6 & 22.3 & -0.7 & 4.9 & 0.8 & 23.6 & 2.2 & 1.3 & 3.1 & 53.8 & 7.9 & 5.6 \\
\hline Phoenix & 9.2 & 30.1 & 3.7 & 3.5 & 5.7 & 48.5 & 5.3 & 9.6 & 12.7 & 50.5 & -3.1 & 1.2 \\
\hline Pittsburgh & 0.2 & 12.5 & 0.7 & -2.8 & 0.2 & 20.0 & -7.3 & 9.3 & 0.5 & 38.3 & -0.9 & 5.6 \\
\hline Riverside CA & 21.2 & 18.3 & 1.0 & 2.3 & 14.8 & 28.7 & 0.5 & 5.3 & 16.2 & 32.8 & 0.4 & 4.7 \\
\hline St. Louis & 0.5 & 15.8 & -1.1 & 2.9 & 0.4 & 20.0 & 3.1 & 5.7 & 0.4 & 24.5 & 0.6 & -2.6 \\
\hline San Diego & 10.5 & 19.2 & 1.5 & 3.9 & 8.2 & 27.9 & 2.7 & 5.0 & 9.3 & 29.6 & 0.7 & 4.1 \\
\hline San Francisco & 7.3 & 21.6 & 2.6 & 6.0 & 9.2 & 21.0 & 1.4 & 4.0 & 6.1 & 28.8 & 2.1 & 4.1 \\
\hline Seattle & 1.2 & 18.7 & 0.5 & 4.9 & 1.2 & 19.0 & 0.1 & 5.1 & 12.6 & 20.4 & 0.8 & 4.3 \\
\hline Tampa & 6.9 & 24.0 & 1.4 & 2.2 & 5.9 & 28.8 & 0.4 & 1.6 & 6.3 & 29.7 & -1.2 & 4.6 \\
\hline Washington & 3.9 & 10.2 & -0.2 & 3.3 & 2.0 & 15.6 & -0.3 & 1.1 & 2.6 & 42.6 & 2.0 & 9.8 \\
\hline Total & 6.6 & 22.1 & 1.4 & 3.7 & 7.7 & 25.6 & 1.6 & 4.9 & 5.7 & 35.4 & 1.4 & 6.2 \\
\hline
\end{tabular}


Table 18: Neighborhood and Unexplained Denial Rate Residuals, Whites, by MSA, 1990 HMDA

\begin{tabular}{|c|c|c|c|c|c|c|c|c|c|c|c|c|}
\hline & \multicolumn{4}{|c|}{ Home Purchase } & \multicolumn{4}{|c|}{ Refinance } & \multicolumn{4}{|c|}{ Home Improvement } \\
\hline & $\begin{array}{l}\text { Percent } \\
\text { White }\end{array}$ & $\begin{array}{l}\text { Denial } \\
\text { Rate }\end{array}$ & $\begin{array}{l}\text { Tract } \\
\text { Effect }\end{array}$ & $\begin{array}{l}\text { Residual } \\
\text { Effect }\end{array}$ & $\begin{array}{l}\text { Percent I } \\
\text { White }\end{array}$ & $\begin{array}{l}\text { Denial } \\
\text { Rate }\end{array}$ & $\begin{array}{l}\text { Tract R } \\
\text { Effect }\end{array}$ & $\begin{array}{l}\text { Residual } \\
\text { Effect }\end{array}$ & $\begin{array}{l}\text { Percent } \\
\text { White }\end{array}$ & $\begin{array}{l}\text { Denial } \\
\text { Rate }\end{array}$ & $\begin{array}{l}\text { Tract } R \\
\text { Effect }\end{array}$ & $\begin{array}{l}\text { Residual } \\
\text { Effect }\end{array}$ \\
\hline All MSAs < 1 Million & $87.4 \%$ & $13.9 \%$ & $-0.2 \%$ & $-0.1 \%$ & $90.0 \%$ & $15.0 \%$ & $-0.2 \%$ & $-0.1 \%$ & $85.3 \%$ & $16.0 \%$ & $-0.5 \%$ & $-0.1 \%$ \\
\hline All MSAs 1 - 2 Million & 83.5 & 12.4 & -0.3 & -0.0 & 85.6 & 16.6 & -0.4 & -0.1 & 81.2 & 23.0 & -1.0 & -0.1 \\
\hline Anaheim & 71.9 & 14.4 & -0.4 & -0.2 & 77.5 & 19.5 & -0.3 & -0.1 & 77.6 & 20.0 & -0.0 & -0.0 \\
\hline Aclanta & 79.3 & 11.6 & -1.2 & -0.3 & 90.0 & 15.2 & -0.2 & 0.0 & 77.2 & 17.1 & -1.2 & -0.7 \\
\hline Baltimore & 81.8 & 9.0 & 0.2 & 0.3 & 90.3 & 12.7 & -0.2 & -0.1 & 69.6 & 28.6 & -2.1 & 0.0 \\
\hline Boston & 88.6 & 12.4 & -0.4 & -0.0 & 92.6 & 16.0 & -0.4 & -0.2 & 89.3 & 16.0 & -0.4 & 0.1 \\
\hline Chicago & 73.6 & 8.1 & -0.7 & 0.1 & 82.3 & 12.9 & -0.9 & -0.0 & 67.9 & 21.1 & -2.4 & -0.1 \\
\hline Cleveland & 89.6 & 9.0 & -0.5 & 0.0 & 91.4 & 15.7 & -0.9 & -0.2 & 79.1 & 23.1 & -1.5 & 0.4 \\
\hline Dallas & 83.3 & 11.1 & -0.3 & 0.1 & 91.7 & 17.4 & -0.4 & 0.2 & 84.4 & 23.9 & -1.4 & -0.8 \\
\hline Detroit & 88.4 & 11.0 & -0.1 & 0.2 & 93.7 & 13.0 & -0.4 & -0.1 & 67.4 & 22.2 & -4.6 & 0.2 \\
\hline Houston & 75.5 & 14.6 & -0.5 & -0.3 & 88.3 & 11.6 & -0.3 & 0.2 & 75.0 & 29.3 & -2.3 & -1.2 \\
\hline Los Angeles & 52.0 & 16.3 & -0.9 & 0.3 & 54.5 & 20.0 & -1.1 & 0.1 & 58.6 & 23.5 & -0.3 & 0.9 \\
\hline Miami & 45.6 & 18.0 & -0.4 & 1.5 & 48.2 & 28.4 & 0.2 & 0.3 & 36.6 & 32.9 & 0.5 & 0.6 \\
\hline Minneapolis & 95.4 & 7.3 & -0.1 & 0.0 & 97.7 & 13.7 & 0.0 & -0.1 & 96.3 & 18.2 & -0.2 & 0.0 \\
\hline Nassau/Suffolk NY & 82.2 & 13.9 & -0.5 & 0.2 & 86.9 & 18.7 & -0.3 & 0.1 & 86.7 & 28.4 & -0.4 & 0.1 \\
\hline New York & 57.5 & 16.5 & .1 .0 & 0.3 & 61.4 & 20.1 & -1.4 & 0.1 & 60.6 & 36.2 & -1.8 & 1.0 \\
\hline Oakland & 64.6 & 11.7 & -0.5 & 0.1 & 66.8 & 15.5 & -0.8 & 0.2 & 72.8 & 19.4 & -0.5 & 0.4 \\
\hline Philadelphia & 83.6 & 9.5 & -0.1 & -0.0 & 92.5 & 14.2 & -0.2 & -0.1 & 78.2 & 28.0 & -2.4 & -0.0 \\
\hline Phoenix & 86.1 & 17.3 & -0.4 & -0.0 & 91.5 & 29.0 & -0.4 & -0.5 & 83.9 & 50.0 & 0.5 & 0.9 \\
\hline Pittsburgh & 94.3 & 13.3 & -0.1 & -0.1 & 97.0 & 12.6 & -0.3 & -0.3 & 88.0 & 26.5 & -1.4 & -0.1 \\
\hline Riverside CA & 65.1 & 16.0 & -0.3 & 0.5 & 74.4 & 22.8 & -0.1 & -0.3 & 72.9 & 25.8 & -0.1 & 0.1 \\
\hline St. Louis & 89.0 & 13.3 & -0.7 & -0.1 & 90.8 & 11.0 & -0.3 & -0.1 & 77.9 & 19.5 & -2.6 & -0.5 \\
\hline San Diego & 78.2 & 13.0 & -0.2 & 0.0 & 82.5 & 19.3 & -0.4 & -0.1 & 76.2 & 21.1 & -0.3 & -0.1 \\
\hline San Francisco & 63.9 & 12.9 & -0.5 & -0.3 & 66.7 & 16.7 & -0.6 & -0.2 & 72.0 & 21.2 & -0.7 & 0.5 \\
\hline Seattle & 86.4 & 13.1 & -0.0 & -0.1 & 90.5 & 12.6 & -0.1 & -0.1 & 87.2 & 15.4 & -0.2 & -0.1 \\
\hline Tampa & 87.2 & 17.9 & -0.3 & 0.1 & 89.3 & 26.1 & -0.2 & -0.0 & 82.7 & 24.6 & -0.2 & 0.2 \\
\hline Washington & 72.2 & 7.7 & -0.1 & 0.2 & 81.9 & 13.4 & -0.3 & 0.2 & 67.4 & 20.3 & -2.0 & -0.3 \\
\hline Total & 81.4 & 13.1 & -0.3 & -0.0 & 80.9 & 16.4 & -0.4 & -0.1 & 79.9 & 20.3 & -0.9 & -0.0 \\
\hline
\end{tabular}


Table 19: Black-White Residuals by Denial Probability, 1990 HMDA

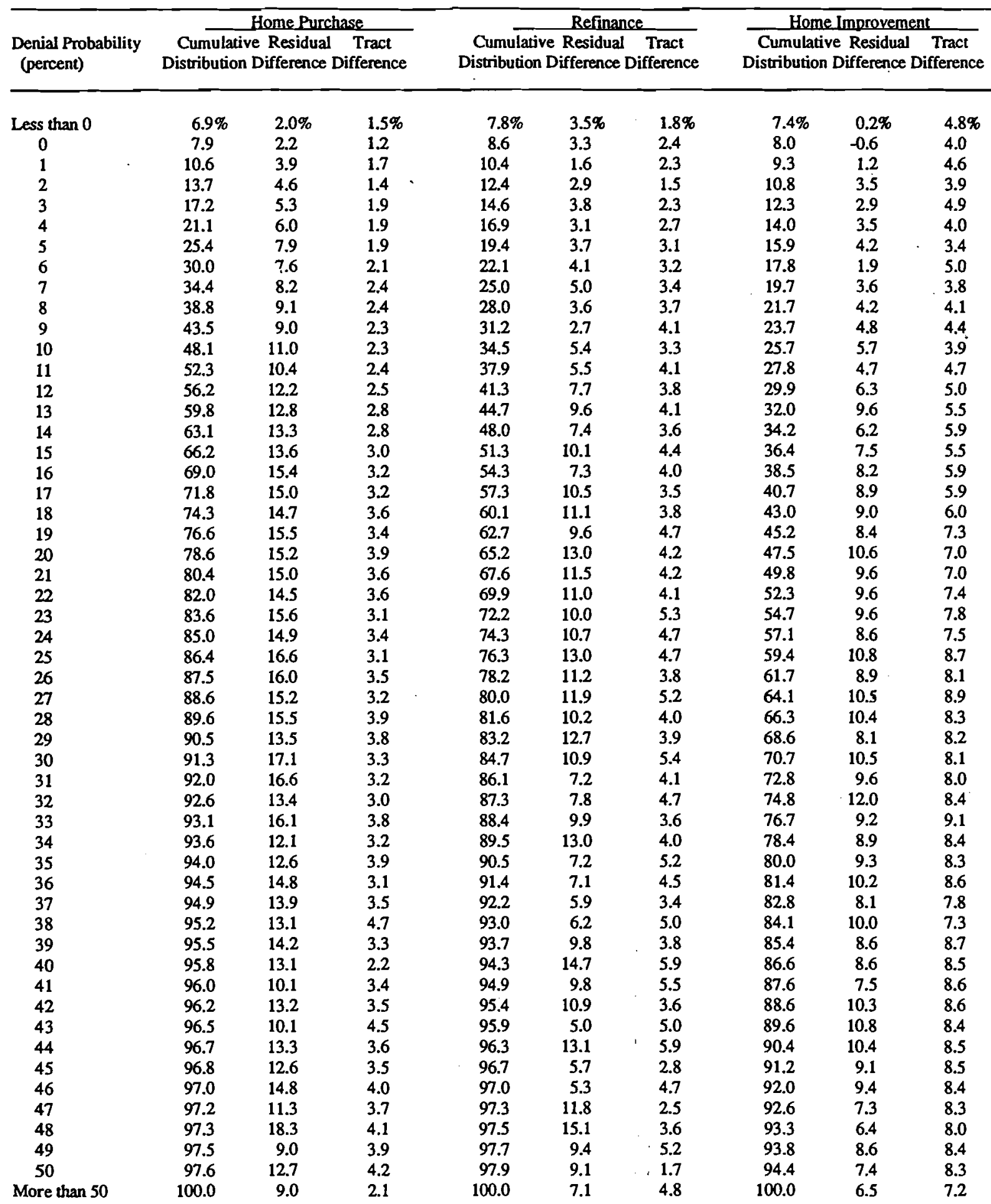


Table 20: Hispanic-White Residuais by Denial Probability, 1990 HMDA

\begin{tabular}{|c|c|c|c|c|c|c|c|c|c|}
\hline \multirow[b]{2}{*}{$\begin{array}{l}\text { Denial Probability } \\
\text { (percent) }\end{array}$} & \multicolumn{3}{|c|}{ Home Purchase } & \multicolumn{3}{|c|}{ Refinance } & \multicolumn{3}{|c|}{ Home Improvement } \\
\hline & \multicolumn{2}{|c|}{$\begin{array}{l}\text { Cumulative Residual } \\
\text { Distribution Difference D }\end{array}$} & $\begin{array}{l}\text { Tract } \\
\text { ifference }\end{array}$ & \multicolumn{3}{|c|}{$\begin{array}{l}\text { Cumulative Residual Tract } \\
\text { Distribution Difference Difference }\end{array}$} & \multicolumn{3}{|c|}{$\begin{array}{l}\text { Cumulative Residual Tract } \\
\text { Distribution Difference Difference }\end{array}$} \\
\hline Less than 0 & $6.9 \%$ & $0.8 \%$ & $0.9 \%$ & $7.8 \%$ & $2.4 \%$ & $0.0 \%$ & $7.4 \%$ & $1.3 \%$ & $1.7 \%$ \\
\hline 0 & 7.9 & 1.2 & 0.7 & 8.6 & -0.4 & 1.3 & 8.0 & 1.5 & 1.4 \\
\hline 1 & 10.6 & 0.6 & 0.9 & 10.4 & 2.0 & 1.3 & 9.3 & 0.0 & 3.0 \\
\hline 2 & 13.7 & 0.9 & 1.1 & 12.4 & 2.2 & 1.4 & 10.8 & 0.7 & 1.0 \\
\hline 3 & 17.2 & 1.3 & 1.3 & 14.6 & 3.1 & 1.4 & 12.3 & 1.4 & 1.8 \\
\hline 4 & 21.1 & 1.4 & 1.4 & 16.9 & 2.4 & 1.9 & 14.0 & 2.5 & 2.3 \\
\hline 5 & 25.4 & 1.9 & 1.8 & 19.4 & 0.5 & 2.5 & 15.9 & 2.7 & 1.4 \\
\hline 6 & 30.0 & 2.3 & 1.9 & 22.1 & 1.5 & 1.9 & 17.8 & 2.9 & 1.7 \\
\hline 7 & 34.4 & 3.7 & 1.7 & 25.0 & 1.3 & 2.1 & 19.7 & 2.3 & 1.6 \\
\hline 8 & 38.8 & 3.5 & 1.9 & 28.0 & 2.0 & 2.5 & 21.7 & 4.9 & 4.4 \\
\hline 9 & 43.5 & 3.4 & 1.9 & 31.2 & 4.1 & 2.6 & 23.7 & 2.4 & 1.2 \\
\hline 10 & 48.1 & 3.0 & 1.8 & 34.5 & 2.6 & 1.9 & 25.7 & 1.7 & 2.3 \\
\hline 11 & 52.3 & 2.8 & 1.8 & 37.9 & 4.2 & 2.5 & 27.8 & 3.3 & 3.9 \\
\hline 12 & 56.2 & 2.9 & 1.8 & 41.3 & 5.4 & 2.4 & 29.9 & 5.1 & 2.5 \\
\hline 13 & 59.8 & 3.6 & 1.8 & 44.7 & 6.0 & 2.4 & 32.0 & 5.5 & 2.2 \\
\hline 14 & 63.1 & 4.3 & 1.8 & 48.0 & 5.0 & 2.4 & 34.2 & 4.2 & 3.1 \\
\hline 15 & 66.2 & 3.9 & 1.6 & 51.3 & 5.9 & 2.4 & 36.4 & 6.5 & 2.4 \\
\hline 16 & 69.0 & 4.4 & 1.8 & 54.3 & 7.0 & 2.7 & 38.5 & 8.9 & 3.1 \\
\hline 17 & 71.8 & 4.1 & 1.6 & 57.3 & 6.4 & 2.1 & 40.7 & 6.0 & 2.9 \\
\hline 18 & 74.3 & 5.1 & 1.7 & 60.1 & 4.8 & 2.9 & 43.0 & 8.1 & 2.5 \\
\hline 19 & 76.6 & 4.5 & 1.8 & 62.7 & 6.7 & 2.1 & 45.2 & 9.5 & 3.0 \\
\hline 20 & 78.6 & 4.3 & 1.8 & 65.2 & 6.7 & 2.7 & $47: 5$ & 8.6 & 3.1 \\
\hline 21 & 80.4 & 5.3 & 1.9 & 67.6 & 7.0 & 2.2 & 49.8 & 6.8 & 2.4 \\
\hline 22 & 82.0 & 4.5 & 1.6 & 69.9 & 3.4 & 2.3 & 52.3 & 4.3 & 2.3 \\
\hline 23 & 83.6 & 4.8 & 1.7 & 72.2 & 6.3 & 2.1 & 54.7 & 7.0 & 1.8 \\
\hline 24 & 85.0 & 4.9 & 1.7 & 74.3 & 6.6 & 2.2 & 57.1 & 7.8 & 2.1 \\
\hline 25 & 86.4 & 7.0 & 1.7 & 76.3 & 2.6 & 2.3 & 59.4 & 9.5 & 1.2 \\
\hline 26 & 87.5 & 5.8 & 1.4 & 78.2 & 4.3 & 1.7 & 61.7 & 10.1 & 1.1 \\
\hline 27 & 88.6 & 3.5 & 1.8 & 80.0 & 4.4 & 2.2 & 64.1 & 8.2 & 1.2 \\
\hline 28 & 89.6 & 7.0 & 1.6 & 81.6 & 8.1 & 2.4 & 66.3 & 7.8 & 2.1 \\
\hline 29 & 90.5 & 8.5 & 2.0 & 83.2 & 7.1 & 2.2 & 68.6 & 5.2 & 1.2 \\
\hline 30 & 91.3 & 9.7 & 2.2 & 84.7 & 9.1 & 2.1 & 70.7 & 6.8 & 1.2 \\
\hline 31 & 92.0 & 3.6 & 1.7 & 86.1 & 5.3 & 2.3 & 72.8 & 8.0 & 1.8 \\
\hline 32 & 92.6 & 5.1 & 2.5 & 87.3 & 8.1 & 1.8 & 74.8 & 7.1 & 1.8 \\
\hline 33 & 93.1 & 6.2 & 1.8 & 88.4 & 6.3 & 2.2 & 76.7 & 6.1 & 2.5 \\
\hline 34 & 93.6 & 6.2 & 2.4 & 89.5 & 8.0 & 2.0 & 78.4 & 9.4 & 1.8 \\
\hline 35 & 94.0 & 9.9 & 2.3 & 90.5 & 8.8 & 2.4 & 80.0 & 9.1 & 2.6 \\
\hline 36 & 94.5 & 8.9 & 2.8 & 91.4 & 2.7 & 2.1 & 81.4 & 10.8 & 1.6 \\
\hline 37 & 94.9 & 5.4 & 3.1 & 92.2 & 5.0 & 2.0 & 82.8 & 7.6 & 2.7 \\
\hline 38 & 95.2 & 5.4 & 2.4 & 93.0 & 4.6 & 3.3 & 84.1 & 8.2 & 2.7 \\
\hline 39 & 95.5 & 4.8 & 2.1 & 93.7 & 6.4 & 1.7 & 85.4 & 7.4 & 2.8 \\
\hline 40 & 95.8 & 4.8 & 1.6 & 94.3 & 5.7 & 1.2 & 86.6 & 6.7 & 2.9 \\
\hline 41 & 96.0 & 7.2 & 1.7 & 94.9 & 8.3 & 2.3 & 87.6 & 5.0 & 2,8 \\
\hline 42 & 96.2 & 2.5 & 2.2 & 95.4 & 7.6 & 1.5 & 88.6 & 13.9 & 2.7 \\
\hline 43 & 96.5 & 6.3 & 1.4 & 95.9 & 6.8 & 1.4 & 89.6 & 10.7 & 3.4 \\
\hline 44 & 96.7 & 3.9 & 2.5 & 96.3 & 9.4 & 2.4 & 90.4 & 5.4 & 3.2 \\
\hline 45 & 96.8 & 5.7 & 2.0 & 96.7 & 9.1 & 1.1 & 91.2 & 4.6 & 3.4 \\
\hline 46 & 97.0 & 7.7 & 2.0 & 97.0 & 9.5 & 1.7 & 92.0 & 6.9 & 2.9 \\
\hline 47 & 97.2 & -0.6 & 1.1 & 97.3 & 9.1 & 1.7 & 92.6 & 5.5 & 3.6 \\
\hline 48 & 97.3 & 4.6 & 2.4 & 97.5 & 14.8 & 4.6 & 93.3 & 5.4 & 2.1 \\
\hline 49 & 97.5 & 10.1 & 1.2 & 97.7 & 11.9 & 4.5 & 93.8 & 8.4 & 1.5 \\
\hline 50 & 97.6 & 7.0 & 2.4 & 97.9 & 9.4 & 1.3 & 94.4 & 4.5 & 3.3 \\
\hline More than 50 & 100.0 & 4.2 & 1.5 & 100.0 & 4.3 & 1.6 & 100.0 & 5.1 & 2.1 \\
\hline
\end{tabular}

